\title{
ENTERPRISES, WORKERS AND SKILLS IN URBAN TIMOR-LESTE
}

\author{
Maitreyi Bordia Das and Philip O’Keefe
}

\begin{abstract}
Like many low-income countries, Timor-Leste faces challenges in providing employment for and increasing the skills of its labor force - challenges made more acute by high fertility rates, a very young population, and the capacity constraints of a new nation. However, there is limited information for policymakers to formulate appropriate policies. The paper presents findings of the first urban enterprises survey in independent Timor-Leste. It explores several aspects of the Timorese urban labor market, including the profile of formal and informal enterprises, their behavior in terms of employment and wage-setting practices, and constraints on firm growth. It also presents findings on the skills and training needs of urban employers, and constraints faced in overcoming skills shortages. It finds a highly informalized urban enterprise scene, where even "formal" enterprises are largely micro-enterprises. While there has been considerable action in terms of new firm creation since independence, there is already surprisingly low job creation or destruction. This is driven by a number of constraints in and outside the labor market. With respect to wages, the impacts of the informal minimum wage policy inherited from the interim international administration suggest the need for caution in future wage policy development. While employers identify many skills gaps, basic literacy, numeracy and language skill needs dominate, and employers appear to value short course and less formal modes of skills training to address their needs. The paper concludes with suggestions for addressing the key constraints identified.
\end{abstract}

The World Bank

Human Development Unit

East Asia and Pacific Region

\section{World Bank Policy Research Working Paper 4177, March 2007}

The Policy Research Working Paper Series disseminates the findings of work in progress to encourage the exchange of ideas about development issues. An objective of the series is to get the findings out quickly, even if the presentations are less than fully polished. The papers carry the names of the authors and should be cited accordingly. The findings, interpretations, and conclusions expressed in this paper are entirely those of the authors. They do not necessarily represent the view of the World Bank, its Executive Directors, or the countries they represent. Policy Research Working Papers are available online at http://econ.worldbank.org. 


\section{ACRONYMS}

$\begin{array}{ll}\text { ADB } & \text { Asian Development Bank } \\ \text { DIT } & \text { Dili Institute of Technology } \\ \text { EP } & \text { Equal Probability } \\ \text { FLFP } & \text { Female Labor Force Participation } \\ \text { GDP } & \text { Gross Domestic Product } \\ \text { ILO } & \text { International Labor Organization } \\ \text { L \& S } & \text { Labor and Solidarity } \\ \text { LM } & \text { Labor Markets } \\ \text { MoECYS } & \text { Ministry of Education, Culture, Youth, and Sports } \\ \text { MW } & \text { Minimum Wage } \\ \text { SLTA } & \text { Sekolah Lanjutan Tingkat Atas (Senior High School) } \\ \text { STM } & \text { Sekolah Teknik Menengah (Technical School) } \\ \text { TLSS } & \text { Timor Living Standards Survey } \\ \text { TVET } & \text { Technical and Vocational Training } \\ \text { UES } & \text { Urban Enterprises Survey } \\ \text { UNMISET } & \text { United Nations Mission of Support in East Timor } \\ \text { UNTAET } & \text { UN Transitional Administration in East Timor }\end{array}$

This report was prepared by Maitreyi Bordia Das and Philip O'Keefe, with inputs from Rui Manual Hanjan. Annex 1 was prepared by Jakob Wichmann. It is primarily based primarily on analysis of a survey conducted by Dili Institute of Technology under leadership of Joao Cancio Freitas, with support from Jakob Wichmann and Rui Manuel Hanjan. The team is grateful to the then Secretariat of Labor and Solidarity (now Ministry for Labor and Community Reinsertion) for its support in survey design and implementation, and to members of the Labor Board who provided suggestions. It is also grateful to Elisabeth Huybens for guidance and support and to Jan Rutkowski, Adrian Fozzard, Alan Abrahart, and Johanna Stenstrom Johansson for comments on an earlier draft. The team also acknowledges the financial support from Government of Denmark which financed the survey on which much of the analysis is based. The survey instruments are available in English and Bahasa from the World Bank Office in Dili, TimorLeste. 


\section{TABLE OF CONTENTS}

\section{Page}

1. Introduction 4

(i). Country Context 4

(ii) The Labor Market in Timor-Leste $\quad 8$

2. Findings of the Timor-Leste Urban Enterprises Survey, 2004 10

(i) Characteristics of Urban Enterprises 11

(ii) Behavior of Urban Enterprises 16

(iii) Wages and Wage Setting $\quad 22$

(iv) Training and Skills in the Urban Labor Market 27

$3 \quad$ Conclusion and recommendations 31

Annex 1: $\quad$ Sampling and Survey Documentation for the UES 36

Annex 2: $\quad$ Definition of Worker Categories in UES 43

Annex 3: $\quad$ Definition of Skills in UES 44

Annex 4: $\quad$ Key Macroeconomic Indicators 45 


\section{Introduction}

\section{(i) Country Context ${ }^{1}$}

1. Since independence, Timor-Leste (TL) has confronted a range of social and economic challenges. Some are related to the economic volatility common to post-conflict countries as reconstruction-related spending rises rapidly and then subsides (though it has performed well in comparison to other post-conflict countries). Some relate to the challenges of establishing institutional and governance structures in a newly independent state with low human capital endowments. Others relate to the efforts of a resource-dependent state to diversify its sources of production and employment. Finally, Timor Leste is a very poor country, with per capita GDP in 2004 of only US $\$ 366$. The challenges to develop a broad-based and sustainable pattern of growth are made more pressing by a high population growth rate and the need for employment of a young population.

2. This report focuses on urban labor markets in Timor-Leste. As in any economy, labor market outcomes are a result of many influences, both inside and outside the labor market itself. Factors outside the LM can include macroeconomic policies, political stability, the business climate, demographics, and the education and training systems. These factors produce a mix of supply and demand side influences on the LM which feed into employment outcomes. They are also likely to have major impacts on the composition of employment between the formal and informal sectors. Promoting employment growth - preferably in the formal sector - is therefore not simply a matter of having employment-friendly labor market policies, but of having the appropriate mix of macro and microeconomic policies. Even with a sensible mix of policies, open economies - particularly small open economies with heavy dependence on a sectorally narrow production base - will remain vulnerable to exogenous shocks. However, many of the employment-promoting policies that make sense in the absence of shocks can be even more important when shocks hit in terms of how rapidly the economy is able to adjust to shocks. This section looks at some of the key developments and policies in Timor-Leste outside the LM in order to provide context to the detailed discussion of urban LMs in the main part of the paper.

3. The growth path of Timor Leste in recent years has been volatile, with both strong positive and negative shocks to the economy in a short period. Violence in 1999 resulted in a sharp drop in non-petroleum GDP, by around 35 percent. This was followed in 2000 and 2001 by high growth of 15 and 17 percent respectively as massive foreign reconstruction aid came in, reaching US\$300 per capita in FY02. The boom years were followed by a strong demand shock in 2002 and 2003 as GDP declined 6 percent in each year, before recovery in 2004 on the back of new petroleum production. However, despite renewed growth, GDP per capita has declined in the face of a high population growth rate. These macroeconomic developments are likely to have had significant impacts on the labor market, both in terms of uncertainty and in terms of geographical concentration in and around Dili of growth even in the periods of positive shocks. Despite the challenging situation, the Government has exercised prudent macroeconomic management.

4. $\quad \mathrm{TL}$ is, and is likely to remain for the foreseeable future, a highly rural economy. Poverty is also higher in rural areas, with around 45 percent of the population below the poverty line in 2000, against around 25 percent in urban areas. Productivity in rural areas is also low,

\footnotetext{
${ }^{1}$ This section draws on the Timor-Leste Country Assistance Strategy (2005) and the Timor-Leste Business Climate Assessment.
} 
with agriculture, livestock, fisheries, and forestry accounting for around 80 percent of all selfemployment in Timor Leste (the dominant form of employment), but only 30 percent of nonpetroleum GDP. A third of the rural population is wholly dependent on subsistence agriculture. Environmental degradation and population pressures suggest that agricultural productivity will be difficult to improve.

5. The economy remains highly dependent on petroleum revenues, which are expected to reach US\$5.8 billion over the coming 20 years. However, this is unlikely to be a source of significant employment, and the country will need to diversify its sources of employment. The coffee industry is presently the major non-petroleum source of production, and 28 percent of households earn some income from coffee. Public sector employment - around 17,000 including the armed forced - is likely to remain a major source of employment for the more skilled.

6. Infrastructure is very under-developed in TL, and factor costs are high. The road network is in very poor condition, and vulnerable to rain and mudslides. Electricity is among the most costly in the world for commercial users. Despite this, access to electricity in district capitals is limited to a few hours per night, and most of the rural population has no access to power. Telecommunications are expensive, with phone calls around four times the price of Indonesia.

7. A relatively positive point of recent development is the financial sector, though progress has been from a very low base. As of mid-2005, there were three commercial banks in operation, with a seven-fold increase in lending between 2003 and 2004. While this lending activity has contributed considerably to growth in assets in Dili, financial services have not to date been widely available outside the capital, although they are growing. Microfinance, which operates mostly outside Dili, is also gaining momentum. While there are therefore institutions serving the high and low ends of the market, there remains a "missing middle" in the sector.

8. As could be expected in a country at TL's income level, social indicators are poor. Around 40 percent of adults are illiterate. On the positive side, access to education has increased dramatically over time, especially for the poor, with net primary enrollment rates reaching about 80 percent. However, net secondary school enrollment is only 30 percent. About one child in ten never goes to school. Health indicators are improving gradually, but remain poor. The mortality rate for children under five has declined from 165 per 1,000 live births in the period 1989-1993 to 83 per 1,000 in the period 1999-2003, and IMR is 85. Yet half of children under five are stunted, and approximately two out of every five non-pregnant women and one out of every four men have a low body-mass index.

9. Given the range of challenges outlined above, the business climate assumes unusual importance in terms of the potential for stimulating employment growth. In this regard, there have been some positive policy developments. Solid progress has been made in completing the regulatory framework for private sector development, with law on commercial societies, insurance, and domestic and foreign investment promulgated. Laws on payments and bankruptcy are currently under development. Despite this, firms face a challenging business environment in many key areas.

10. A recent Business Climate Assessment for Timor-Leste provides a useful comparative picture of the national business climate along a range of dimensions. Overall, in comparative terms, the business climate in Timor-Leste is not conducive to easy operation of formal businesses, with the ability to enforce contracts a particularly problematic area, with Timor-Leste ranked the worst performer in the world on this indicator in 2006 Doing Business. The business 
climate therefore appears likely to limit business (and hence employment) growth. Some key findings in this respect are as follows:

- $\quad$ The time and particularly costs involved in starting a business in Timor-Leste are high relative not only to developed countries but also to many neighboring countries. This can be seen in Figure 1. In Timor-Leste, the average number of days required to start a business is 92 days. This is less than a number of developing countries such as Indonesia, Mozambique and Brazil, but substantially higher than many Pacific and East Asian countries. In terms of the cost of staring a business (relative to income per capita), the costs in Timor-Leste are even higher, at 125 percent of GDP per capita. This compares to Indonesia at 102 percent of GDP, Mozambique at 95 percent, and East Asian countries much lower, at 30 percent in PNG, 21 percent in Malaysia, 6 percent in Thailand, and only 3 percent in Hon Kong.

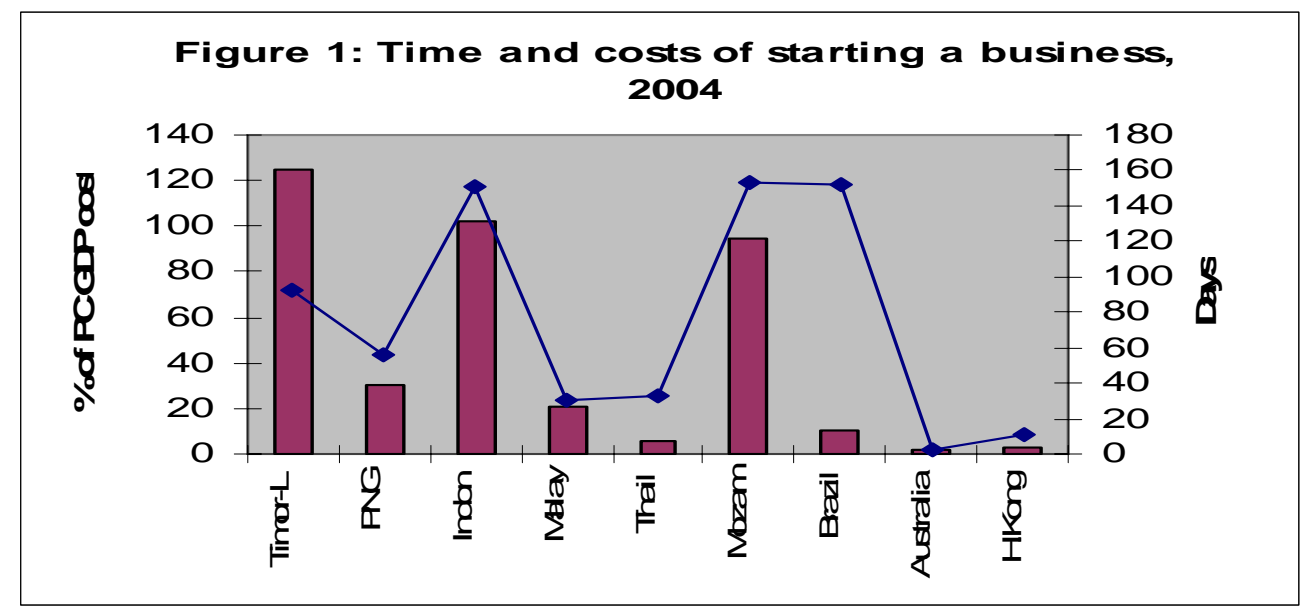

Source: World Bank, Doing Business, 2006.

- The flexibility of labor regulations is another factor in incentives to formality and willingness to hire new workers. Relative to most East Asian and Pacific countries, Timor-Leste's labor regulations are reasonably rigid, though less so than both Indonesia and the bulk of Lucaphone countries. The comparative flexibility of labor regulations is shown in Figure 2, where lower scores indicate greater flexibility and higher scores less flexibility. The index is composed of sub-indicators on difficulty of hiring and firing, and rigidity of work hours. On the sub-items, Timor-Leste stands out as having a particularly difficult environment for hiring of workers.

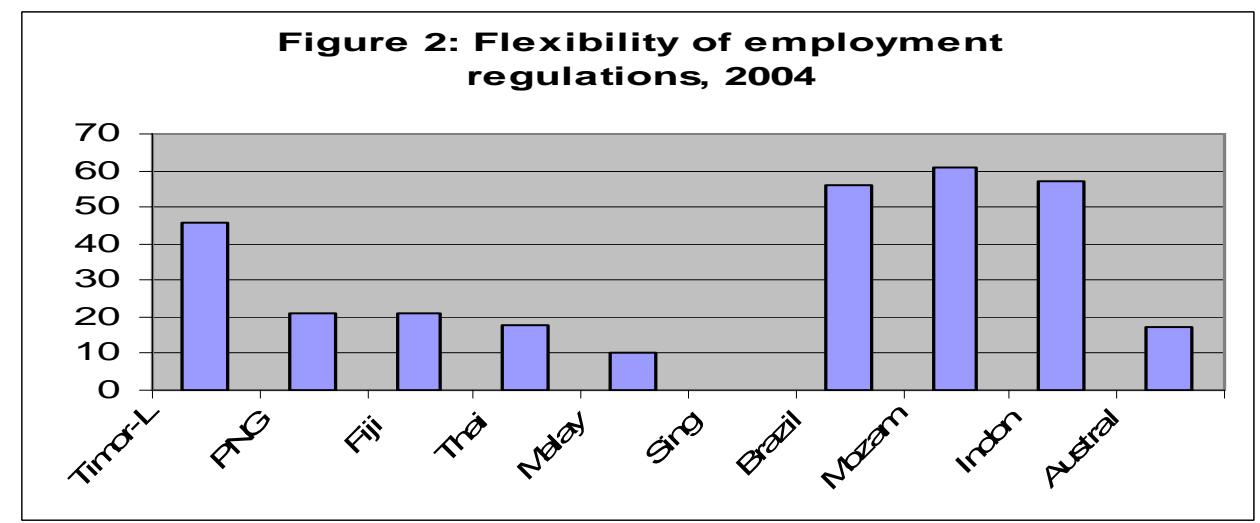


- $\quad$ For a country such as Timor-Leste with very limited domestic capital, a negligible indigenous industrial base and dependence on technology-intensive industry such as oil, the degree to which policy stimulates investment and trade is unusually important. Figure 3 shows an index of protection provided under local law to foreign investors, and indicates that Timor-Leste provides weak protection to foreign investors relative to regional comparators.

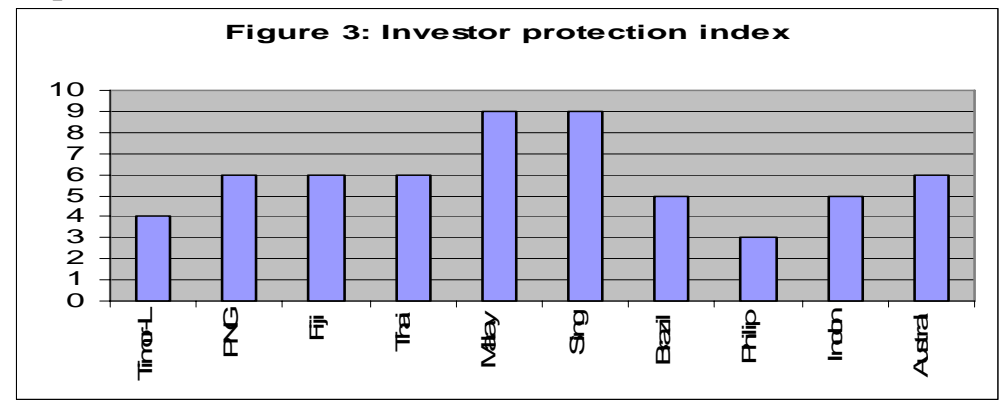

Source: WB, DB, 2006. Higher numbers = more protection.

- $\quad$ as businesses become formal and grow, they become increasingly dependent on their ability to enforce contracts with business partners, workers, and creditors/debtors. The time and cost of contract enforcement is therefore a critical factor in the incentives that businesses face. Comparative findings on this question are presented in Figure 4. Timor-Leste is a clear outlier in terms of both time and costs involved in enforcing contracts, being dramatically higher on both counts than all regional comparators.

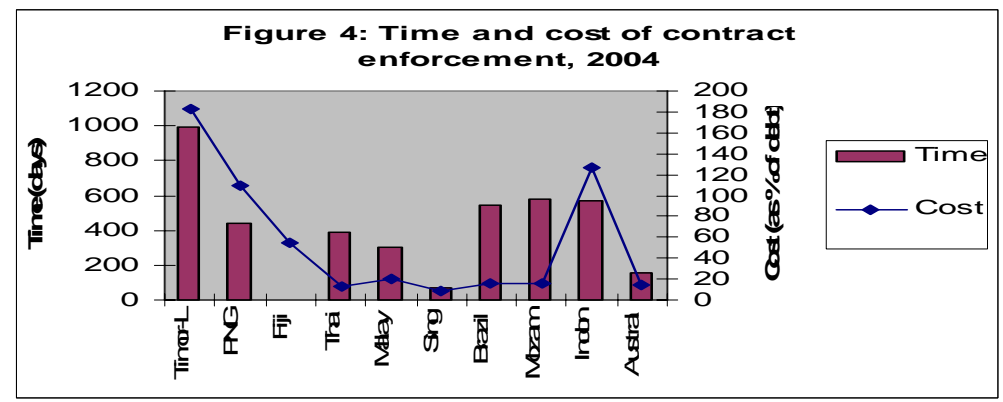

Source: WB, DB, 2006.

11. In summary, it is clear that macroeconomic shocks, inherited structural challenges and in some areas current policies are major factors in any discussion of labor markets in Timor-Leste. Even the most smoothly functioning labor markets would have struggled to generate sustainable employment in the face of such conditions. This is even more the case when the young and growing population structure of Timor-Leste is taken into account (see below in LM discussion). However, the challenging context within which employment is taking place makes the need for employment-promoting policies within the labor market even more important, as Timor-Leste can not afford the luxury of letting sustained high growth overcome any shortcomings of labor and related policies. The following section discusses LM developments within Timor-Leste which have taken place in the face of the challenging macro environment. 


\section{(ii) The Labor Market in Timor-Leste}

12. (i) Labor Market data: Data on Timor-Leste in general, and on its labor markets in particular, are extremely weak and this hinders effective policy analysis and advice. The Timor Living Standards Survey (TLSS) of 2000 is considered the most reliable and comprehensive information, but reflects living standards and labor market conditions immediately following the end of Indonesian occupation, when major donor presence created specific labor market dynamics in Dili and to some extent beyond which were unlikely to reflect a longer-run equilibrium. Census data collected in 2004 are more recent, but naturally provide a much less comprehensive picture of living standards and employment patterns, and are yet to be analyzed at the unit record level.

13. Given the paucity of up-to-date labor market information, a survey of formal and informal urban enterprises was carried out in August-September 2004 in Dili, Baucau and Maliana, with financial support from the Danish Government and the World Bank, and with the endorsement of the then Secretariat of Labor and Solidarity (L\&S), now the Ministry for Labor and Community Reinsertion. The objectives of the survey were to:

- $\quad$ Provide up-to-date information on some key elements of urban labor markets, including firm features and needs, worker characteristics, wages, and skills issues. While the information gathered was limited, it is nonetheless considered useful in such as data-poor environment.

- $\quad$ Act as a resource for Government officials, Labor Boards, employers and unions, and other key stakeholders as they develop labor and employment policy.

- $\quad$ Inform the policy advice of the World Bank and other agencies on labor, employment and skills issues.

- Inform the design of future household/labor and enterprise surveys through identification of areas needing more detailed enquiry.

14. For all practical purposes, this was a survey of all formal enterprises (a census), which were the existing enterprises on the business register in the towns surveyed, and numbered $494 .^{2}$ In addition, a representative sample of 552 informal/household establishments was also surveyed, to understand their characteristics and role in employment generation. There were separate survey instruments for formal and informal enterprises, with a common core of questions. The details of the survey are provided in Annex 1. This study reports the findings of the survey, also drawing on earlier work on wage policy and the training and vocational education (TVET) system in Timor Leste. ${ }^{3}$

15. (ii) Labor Market features: Timor-Leste is a primarily agrarian economy, dominated by self-employed workers. Below is a short overview of labor market features in Timor Leste, based mainly on the TLSS. The main LM characteristics are:

a. Unemployment Rates: Timor-Leste has high urban unemployment (ILO definition) with workers in Dili/Baucau facing the highest unemployment rates at 20 percent. In rural areas, unemployment is low, but underemployment is suspected to be high, and productivity low.

\footnotetext{
${ }^{2}$ The business register contained significantly more enterprises, but many were found to be no longer in existence by survey enumerators.

${ }^{3}$ Das, Maitreyi (2004) on wage policy and Abrahart (2003a and 2003b) on TVET.
} 
b. Labor Force Participation by Gender and Education: Labor force participation rates are significantly higher for men (81 percent) than for women (40 percent). In fact, one of the major puzzles in Timor Leste is that female labor force participation (FLFP) rates seem to be very low (as measured by the TLSS). In a regime of high poverty, such low FLFP may point to measurement problems on women's work. This is discussed in a later section.

c. Unemployment is higher among the educated than the non-educated, a pattern seen in many developing countries. In a regime of scarce employment opportunities, those with no schooling are most likely to be in the labor force, probably because they can less afford not to be working (or looking for work) compared to those with more education. Finally, in terms of the gender gap, one fourth of the women compared to one in seven men are unemployed, so that concerns about female unemployment are an important factor in Timor Leste.

Figure 5: Timor-Leste: Proportion of Working-Age and Youth Population to Total (20002050)

Source: Calculated from International Database, US Census

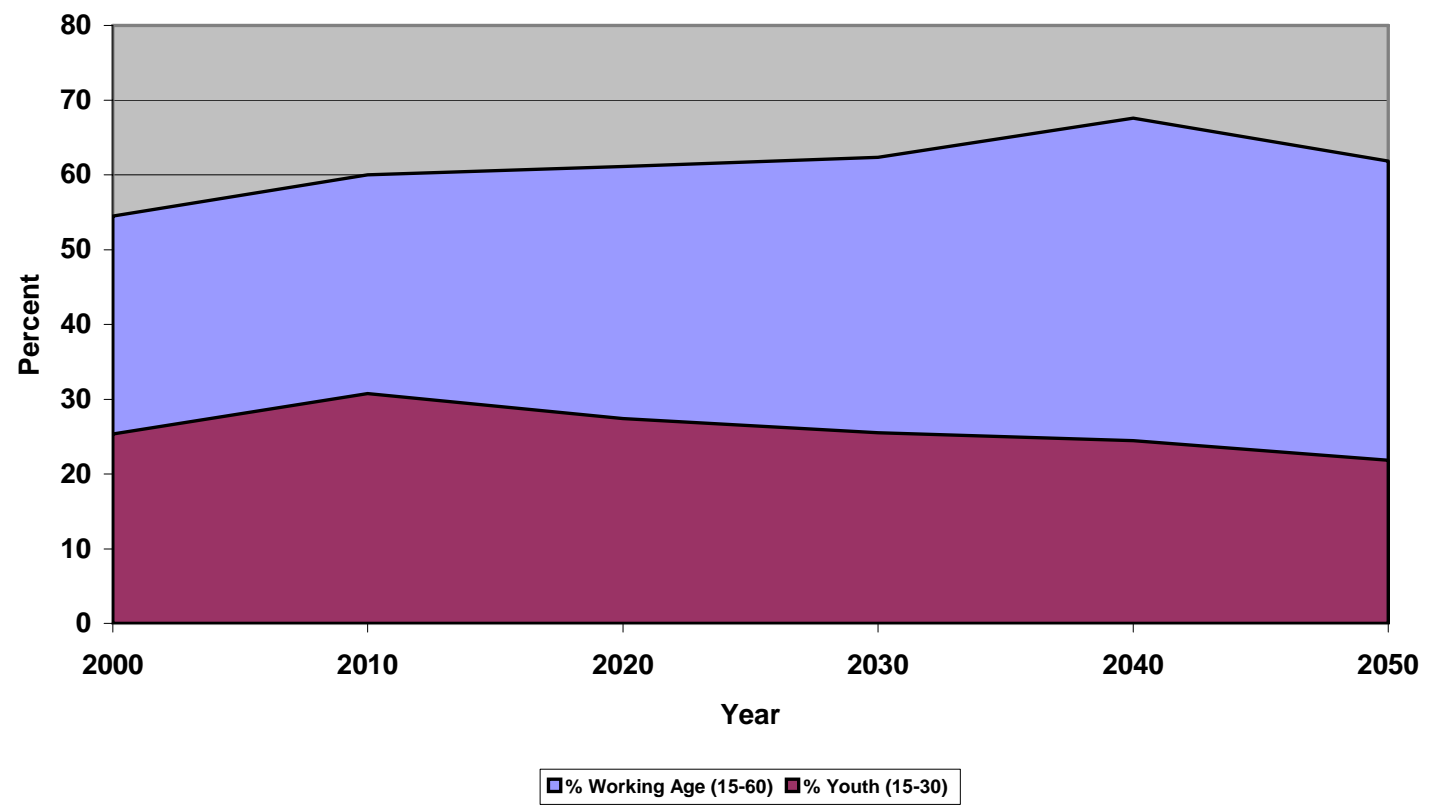

d. Large youth cohorts and high urban youth unemployment: Timor-Leste has an increasingly young population and will be seeing higher numbers of young workers entering the workforce in coming years due to its demographic profile. The ability of the labor market to absorb the large inflows of young workers will be a key social and economic challenge in the short term, but also the medium term (Figure 5). As of 2001, unemployment rates were highest among the youngest cohorts in urban areas and declined sharply with age. Thus, unemployment rates among urban 15-24 year olds were 43 percent, but declined to 17 percent for the 25-34 years olds, and nine percent of the over-35 year olds. Thus, a major issue in Timor-Leste's employment policy will likely be how to control and in time reduce youth unemployment.

e. Importance of small firms and self-employment: In 2001, a little less than 4 percent of the employment in Timor-Leste was in the manufacturing sector, and self-employment was the 
dominant employment type. The smallest firms are typically in the informal sector and constitute a survival strategy for the poorest in many developing countries.

f. Skill Levels: Timor-Leste has a shortage of skilled workers, as proxied by average years of schooling, which in 2001 was 4.62 years. Only 4.25 percent of the TLSS sample had attended university. This has a bearing on both productivity and the potential of the country to attract foreign investment. This is borne out by the results of the present survey as well.

g. Labor laws and growth of collective bargaining: Unions and legal institutions in TimorLeste are in a formative phase and rely on support from their Australian counterparts, the ILO and other global umbrella organizations. The unions get their legal standing from the Labor Code. The law permits workers to form and join worker organizations without prior authorization. However, attempts to organize workers generally have been slowed by inexperience and a lack of organizational skills. The Labor Code also provides for a maximum workweek and overtime, minimum standards of worker health and safety, days off, and other standard benefits. The law treats all workers, legal and illegal, the same in terms of wages and working conditions. As required by the Labor Code, the Government nominated members to the National Labor Board, the Labor Relations Board, and the Minimum Wage Board. These boards begun work in 2004 and are receiving training.

\section{Findings of the Urban Enterprises Survey 2004}

16. As outlined above, in order to address the gaps in knowledge about the urban labor market and investment climate, during August-September 2004, a survey of 487 formal and 552 informal establishments was fielded in Dili, Baucau and Maliana districts. The survey was administered to the manager or owner of the enterprise, whoever was available. The main aim of the survey was to get information on size, dynamism and characteristics of the enterprises, wages, wage setting, barriers to growth, and their relationship to jobs and skills in Timor Leste. In addition, the Government as well as key stakeholders such as trade unions, employers, researchers and donors were keen to get information on existing skills of workers, the demand of further skills development and the importance of existing labor market institutions and laws.

17. The survey asked questions on sector and place of operation, number of workers employed in types of jobs, annual turnover source of startup capital, growth in employment over time, hiring practices, training provided, needs of employers in terms of trained employees, social protection provided to employees, and some information on wages. Also, the survey asked enterprises about the potential impact of a minimum wage if it were enforced. Timor-Leste is currently considering the legislation of a MW and there is some controversy, as to whether this would adversely affect employment. The survey provides important information about the potential impact of such a MW.

18. In the absence of basic information on enterprises and the labor market, the survey is a useful step. The findings are presented in the following sections. However, it also had some important limitations, due to which it provides at best a "quick and dirty" understanding of the urban labor market, and which imply important caveats on the analysis, including:

- $\quad$ The survey was conducted over a short period, and thus is subject to issues of seasonality.

- $\quad$ Since the survey was intended to elicit responses from employees about their enterprises, a large number of questions were perception based. These introduce subjectivity, which 
makes an analysis of the labor market difficult. On some questions respondents could also provide multiple answers without ranking.

- $\quad$ Since questions were asked only of employers or managers, and not of employees, this provides a picture of the functioning of the firm. Its lack of connection to a household survey or a survey of employees prevents it from being a comprehensive analysis of the labor market.

- Translation of the questionnaire into Bahasa Indonesian and the re-translation of the responses into English posed challenges.

\section{(i) Characteristics of Urban Enterprises}

19. (a) Employment in Urban Enterprises: Urban enterprises, even formal ones, are very small establishments. Table 1 below shows that almost three-fourths of formal enterprises have less than 10 workers, almost one-fifth employ 10-20 persons, and a little over 8 percent have more than 20 workers. Thus, even most formal enterprises would conform to the international definition of microenterprises and some would be considered small enterprises. Only a very small proportion is large or even medium enterprises.

Table 1: Distribution of Number of Workers in Formal Enterprises

\begin{tabular}{|l|c|}
\hline Number of Workers & Percent of Formal Enterprises \\
\hline Less than 10 & 72.4 \\
\hline 10 to 20 & 19.1 \\
\hline $21-50$ & 6.7 \\
\hline $51-100$ & 1.4 \\
\hline More than 100 & 0.4 \\
\hline Total & 100 \\
\hline \multicolumn{2}{|l|}{ Source: Urban Enterprises Survey (UES), 2004. }
\end{tabular}

20. Informal enterprises seem almost entirely to be household ventures, operating with the labor of the owner or family members. Table 2 shows that over 53 percent of informal enterprises have only one person, about 47 percent employing between 2-10 and less than 0.5 percent having over 10 workers. The majority of the workers in household enterprises are family workers and large numbers are either unpaid or paid in kind. Therefore, informal enterprises are not a major source of employment for workers other than their owners.

Table 2: Distribution of Number of Workers in Urban Informal Enterprises
\begin{tabular}{|l|c|}
\hline Number of Workers & Percent of Informal Enterprises \\
\hline 1 & 52.7 \\
\hline $2-10$ & 46.9 \\
\hline $10-20$ & 0.2 \\
\hline $21-50$ & 0.2 \\
\hline Total & 100.00 \\
\hline
\end{tabular}

Source: UES, 2004.

21. Since there is little information on gender differences in employment in Timor-Leste, the results of the survey are important. Ownership by sex showed that owners of formal enterprises were predominantly men, the gender differences among wage workers in these enterprises tell a familiar story. The gender gap by skill level appears to be the most pronounced among manual, and less so among service workers. Either manual work in formal enterprises is considered a “male” job, or women's' skill level in manual work is limited and hence they are unlikely to be in 
these jobs. Since manual workers also comprise the largest single category of workers in formal enterprises (Table 3), the closure of this avenue may contribute significantly to women's low participation in urban employment. The gender gap narrows with higher skill levels, but administrative, technical and managerial workers form such a small proportion of the total workforce in formal enterprises that this does not have a major impact on women's employment.

Table 3: Distribution of workers by skill-level and sex in formal enterprises

\begin{tabular}{|l|c|c|}
\hline & Average number of male workers & Average number of female workers \\
\hline Manual & 6.9 & 1.0 \\
\hline Service & 4.4 & 1.3 \\
\hline Administrative & 2.8 & 0.8 \\
\hline Technical & 2.7 & 0.3 \\
\hline Managerial & 1.4 & 0.2 \\
\hline \multicolumn{2}{|c|}{ Source, UES, 2004. }
\end{tabular}

22. (b) Scale of Operation of Urban Enterprises: Information obtained on turnover of urban enterprises confirms their small size, with the large majority being very small ventures and only a minority medium or large. Table 4 shows that over 15 percent of formal and almost half of informal enterprises have an annual turnover of under USD 1000. Overall, over 93 percent of informal and over 60 percent of formal enterprises have an annual turnover of under USD 10,000.

Table 4: Annual Turnover of Urban Enterprises

\begin{tabular}{|l|c|c|c|c|c|c|}
\hline Annual Turnover USD & \multicolumn{2}{|c|}{ Number of Firms } & \multicolumn{2}{c|}{ Percent Firms } & \multicolumn{2}{c|}{ Cumulative Frequency (\%) } \\
\hline & Formal & Informal & Formal & Informal & Formal & Informal \\
\hline $0-1,000$ & 74 & 254 & 15.4 & 46.6 & 15.4 & 46.6 \\
\hline $1,001-5,000$ & 144 & 213 & 29.9 & 39.1 & 45.2 & 85.7 \\
\hline $5,001-10,000$ & 73 & 45 & 15.2 & 8.3 & 60.4 & 93.9 \\
\hline $10,001-20,000$ & 59 & 23 & 12.2 & 4.2 & 72.6 & 98.2 \\
\hline $20,001-50,000$ & 53 & 5 & 11.0 & 0.9 & 83.6 & 99.1 \\
\hline $50,001-150,000$ & 47 & 3 & 9.8 & 0.6 & 93.4 & 99.6 \\
\hline $150,000-500,000$ & 15 & & 3.1 & & 96.5 & \\
\hline $500,000-1,000,000$ & 8 & & 1.7 & & 98.1 & \\
\hline $150,001-1,000,000$ & & 1 & & 0.2 & & 99.8 \\
\hline $1,000,000$ & 9 & 1 & 1.9 & 0.2 & & 100 \\
\hline Total & $\mathbf{4 8 2}$ & $\mathbf{5 4 5}$ & $\mathbf{1 0 0}$ & $\mathbf{1 0 0}$ & $\mathbf{1 0 0}$ & \\
\hline
\end{tabular}

Source: UES, 2004.

23. (c) Sectoral Composition of Urban Enterprises: In keeping with trends in other low-income countries, urban enterprises in Timor-Leste are predominantly in trading and to a lesser extent in the construction and services sector. Informal enterprises are almost entirely small trading ventures - perhaps operating from the home and street stalls as vendors and hawkers, as well as petty repair shops (see also section on location of enterprise).

24. (i) Formal Sector: Over two-fifths of formal enterprises operate in wholesale and retail trade and in maintenance and repair. Another one-fifth operates in the construction sector. This is in keeping with the understanding that construction is a growing sector in TL. ${ }^{4}$ Services such as health, education and other social services make up another 18 percent of formal enterprises. Hotels and restaurants are 12 percent of these enterprises, while mining is only 5 percent and manufacturing even lower, at less than 3 percent (consistent with TLSS). Therefore, to reiterate: trading, of diverse kinds and perhaps heterogeneous - is at the core of formal

${ }^{4}$ Wichmann, 2003. 
enterprises, and growth in construction and hotels are a symbol of economic growth. Services are more in the nature of private hospitals, clinics, schools, hotels and restaurants. How persistent employment in these sectors will be in the face of macroeconomic slowdown remains to be seen.

Table 5: Sectoral Composition of Urban Formal Enterprises

\begin{tabular}{|l|c|}
\hline Industry & Percent Formal Enterprises \\
\hline Wholesale/Retail Trade \& Maintenance/Repair & 40.7 \\
\hline Construction & 19.8 \\
\hline Health, Education \& Other Social Services & 17.8 \\
\hline Other & 12.8 \\
\hline Hotels \& Restaurants & 12.4 \\
\hline Transport, Storage Communication & 5.4 \\
\hline Mining, Quarry, Electricity, Gas & 3.1 \\
\hline Manufacturing & 2.5 \\
\hline Agriculture \& Allied & 0.8 \\
\hline
\end{tabular}

Source: UES, 2004.

25. When disaggregated by size of enterprise, we find a surprising homogeneity in sector of operation, with trading dominating every category of enterprise - from the micro to the large (Figure 6). Thus, the picture of a predominantly petty trading economy in urban areas emerges. Among significant sectors, it is construction and hotel business where a relatively greater heterogeneity appears. Thus, while only about 11 percent of the smallest enterprises are in the construction sector, over 21 percent of the small and medium enterprises are in construction. Similarly, while only about 8-9 percent of the micro (smallest) and small enterprises are in the hotel business, this proportion increases to over 17 percent for enterprises with a turnover of over USD 1000.

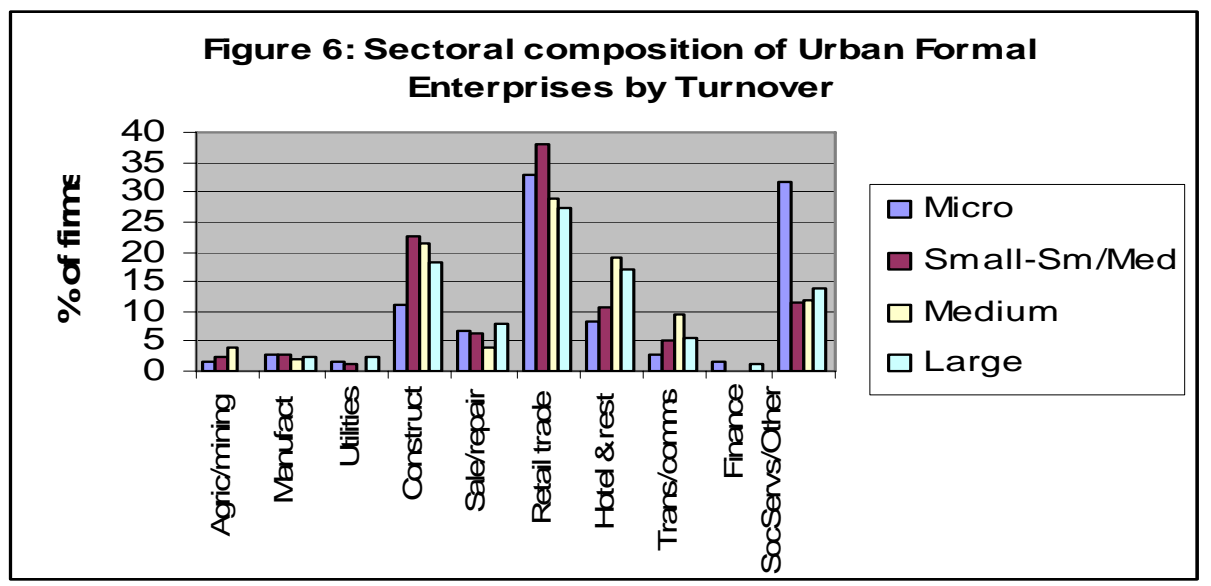

Source: UES, 2004.

26. (ii) Informal sector: Informal enterprises are almost entirely (93 percent) in trading and petty maintenance (e.g. auto, bicycle, small machinery repair). About 3 percent of informal enterprises are in the hotel and restaurant business and 2 percent are in services (see Figure 7). 


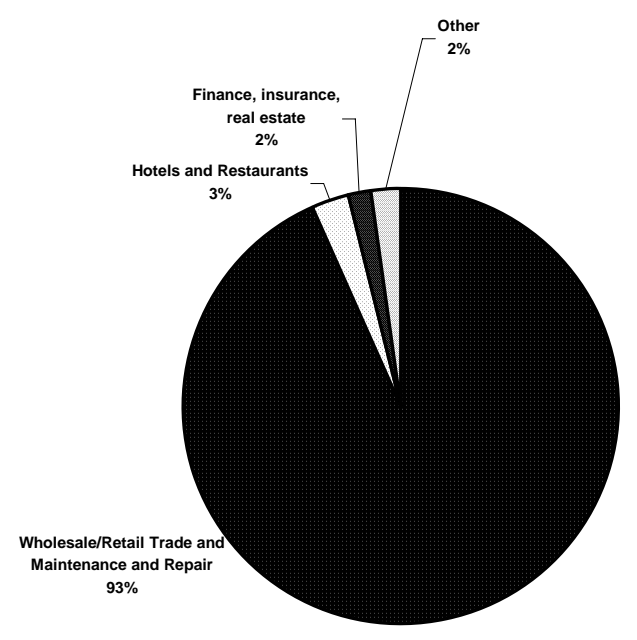

Source: UES, 2004

27. (d) Ownership of enterprises: Ownership issues in the enterprises were assessed through questions on nationality, age and sex. The main findings are:

i. $\quad$ National Origin: The majority of formal enterprises are owned by Timorese who lived in Timor Leste prior to 1999 (see Figure 8). However, while they constitute three-quarters of the owners of enterprises whose turnover is less than USD 10,000, their share declines as the turnover of enterprises grows, and foreign firms acquire an increasing (though still not dominant) share.

ii. Gender: One of the major conundrums in Timor Leste is that female labor force participation (FLFP) rates seem to be very low as measured by the TLSS, despite high poverty in the country. When we look at the ownership of enterprises by sex, we find that only 16 percent of the formal, but almost 43 percent of informal, enterprises are owned by women (see Figure 9). This may be due to measurement and response bias. In most developing countries, women are more likely than men to be self-employed, rather than wage employed. Moreover, they are also more likely than men to be unpaid workers in household enterprises. For these reasons and others (such as the often part-time and seasonal nature of their work), their participation in the labor force is often undermeasured. In the case of Timor-Leste, since the differentials by sex in formal and informal enterprises are so distinct that we may speculate that the TLSS may have under-measured women's labor force participation. On the other hand, it is also possible that women are more likely to be in the informal and less in the formal sector. But ownership is only part of the story of gender differences in the urban labor market. Women's participation in wage work in these enterprises is discussed in another section. 


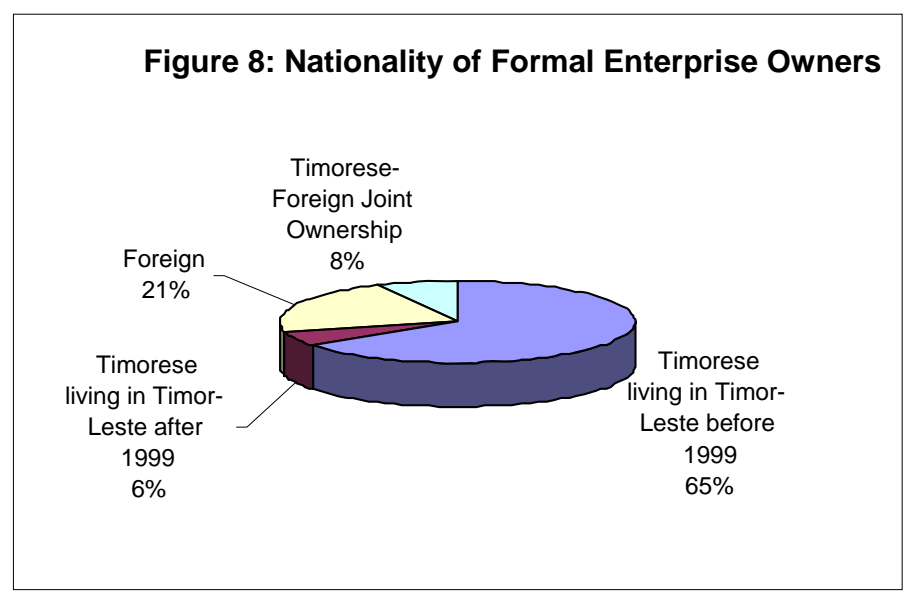

Source: UES, 2004.

iii. Age: An analysis of ownership of the enterprises by age shows that owners are on average below 40 years of age. The mean age for owners of formal enterprises is 39 years, the range is 18-82 and their median age is 38.5. In the case of informal enterprises, the average and median ages of owners too are only slightly different at 37 and 35 years respectively (see Figure 10).

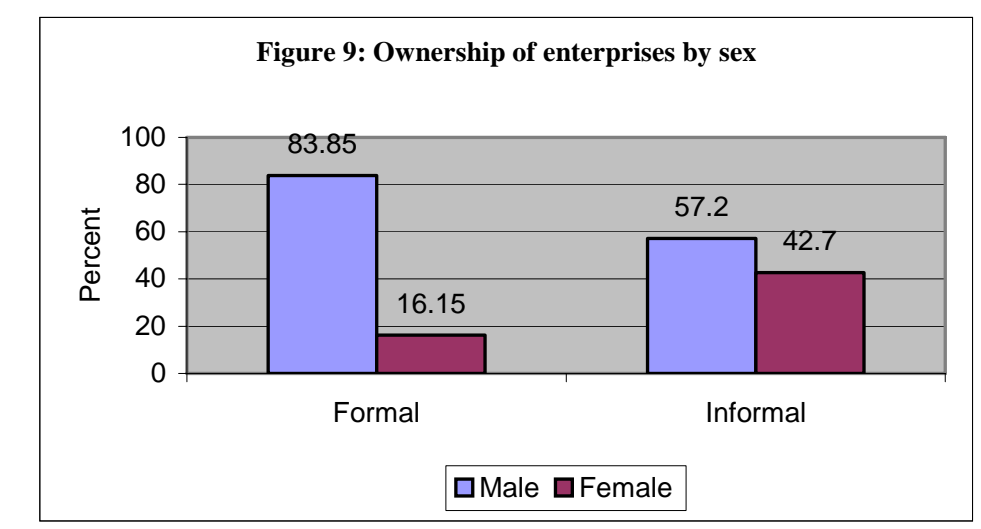

Source: UES, 2004.

28. Location: Where do these enterprises operate from and does this give us an indication of their size and scale of operation ? The results are presented in Figure 11. Only one-fourth of the informal and about 38 percent of formal enterprises have a "formal" place of business such as a factory, shop or kiosk. Conversely, almost 61 percent of the informal and about 43 percent of the formal enterprises are home-based. While the former is no surprise, the latter points to the fact that even formal enterprises are small and have characteristics of informality.

29. Overall, the snapshot that emerges is not of formal establishments that have manufacturing businesses, but that of enterprises that are small, operating from the home or from construction sites (perhaps as construction contractors rather than large construction companies). Informal businesses clearly appear to be very small family owned enterprises that operate from the home, or streets and market stalls. This is consistent with the sectors in which these enterprises operate (trading and petty services dominating). 
Figure 10: Age distribution of owners of urban formal and informal enterprises

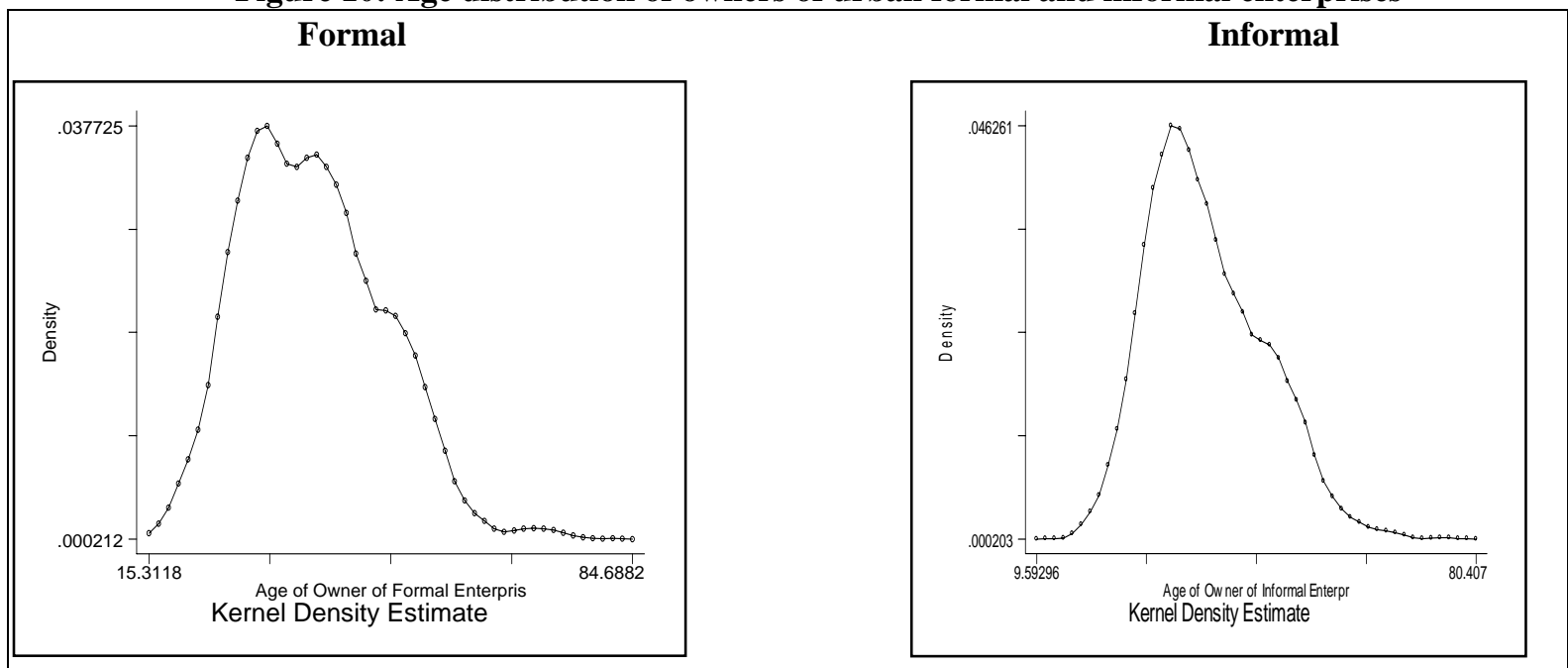

Source: UES, 2004.

30. In keeping with the sectoral composition of formal enterprises, discussed later, over onetenth operate out of construction sites. About 13 percent of the informal establishments operate through street and market stalls, or as mobile vendors. This lack of a fixed place of work and predominantly home-based work of informal enterprises, conforms to the picture of informality that exists in most developing countries in Asia.

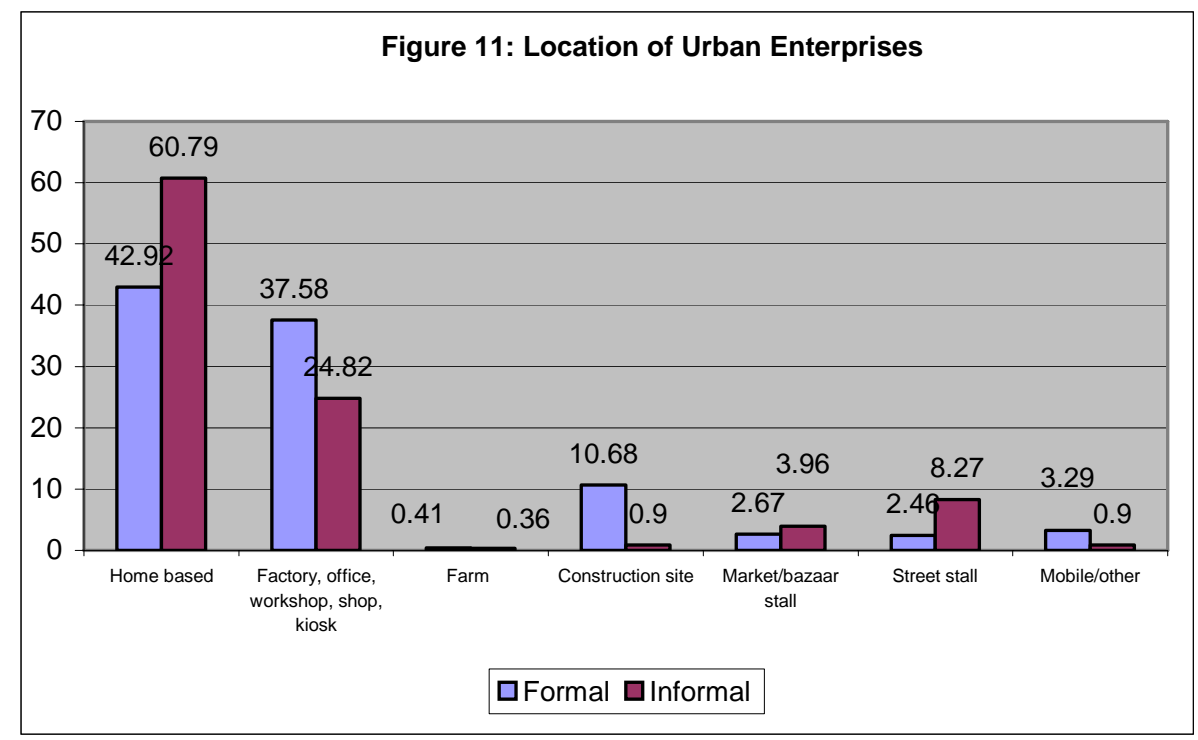

Source: UES, 2004.

\section{(ii) Behavior of Urban Enterprises}

31. This section lays out the insights obtained from questions on the behavior of urban enterprises, including their growth trajectory, constraints to growth, startup capital, hiring practices and non-wage benefits provided.

32. (a) Growth Trajectory and Volatility: The growth of urban enterprises shows that Timorese urban firms are very new, and still exhibit large fluctuations. This suggest that the economy continues to stabilize, but also reflects the volatility of new entry small firms. It is 
likely that - as in the rest of both developed and developing worlds - new firms may have high failure rates in the first few years and find it difficult to grow. In terms of employment, while informal enterprises employ the bulk of the urban labor force, their growth has been slow if not stagnant in the last two years.

33. (i) Growth in Number of Firms: Figure 12 shows that the vast majority of the formal firms started after 1999, with the largest burst in numbers occurring between 1999 and 2000, and after a slight decline in 2001, there was again an increase in 2002, followed by another decline in 2003 and the first three quarters of 2004. ${ }^{5}$ Although the survey was in the field only until September 2004, the decline in numbers of enterprises between 2003 and 2004 seems to point to the effects of the withdrawal of UNMISET. Informal enterprises show a similar trajectory, though with a much less sharp decline after 2003 compared to formal units, probably because they cater to the local market, rather than the expatriate market. Overall, the numbers prior to 1999 should not be given great attention, as they most likely simply reflect dominant Indonesian ownership of businesses during the occupation period.

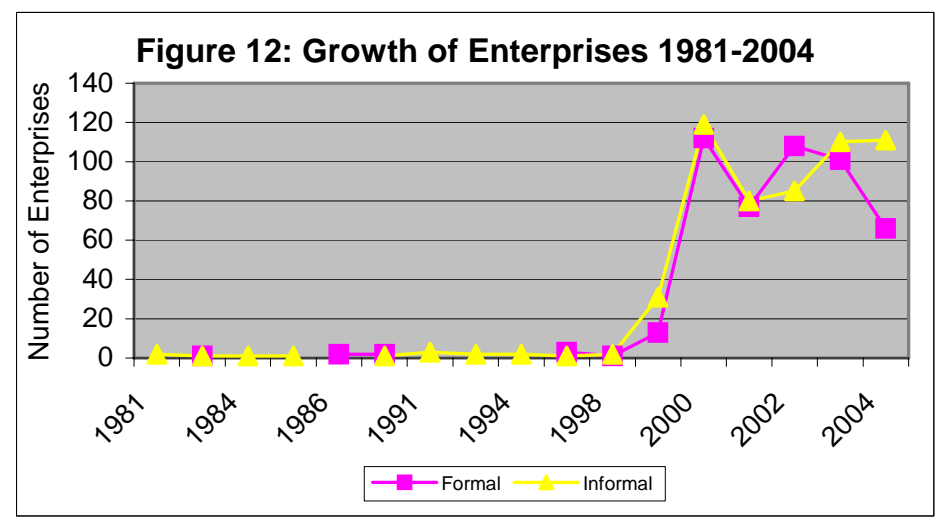

Source: UES, 2004

34. (ii) Employment Dynamics: Over the last two years, the bulk of enterprises - both formal and informal - remained unchanged in their number of workers, though there appears to be a net increase in hiring in 10 percent of formal enterprises (see Figure 13). The informal sector in particular is virtually stagnant, with neither job creation nor destruction, reflecting the family nature of establishments. In the context of increasing inflow into the labor force, with growing cohorts of youth, the failure of firms to create net employment (or even to generate job turnover, which might be a source of productivity growth) is problematic for the economy.

\footnotetext{
${ }^{5}$ Clearly this is in reference to non-Indonesian firms.
} 


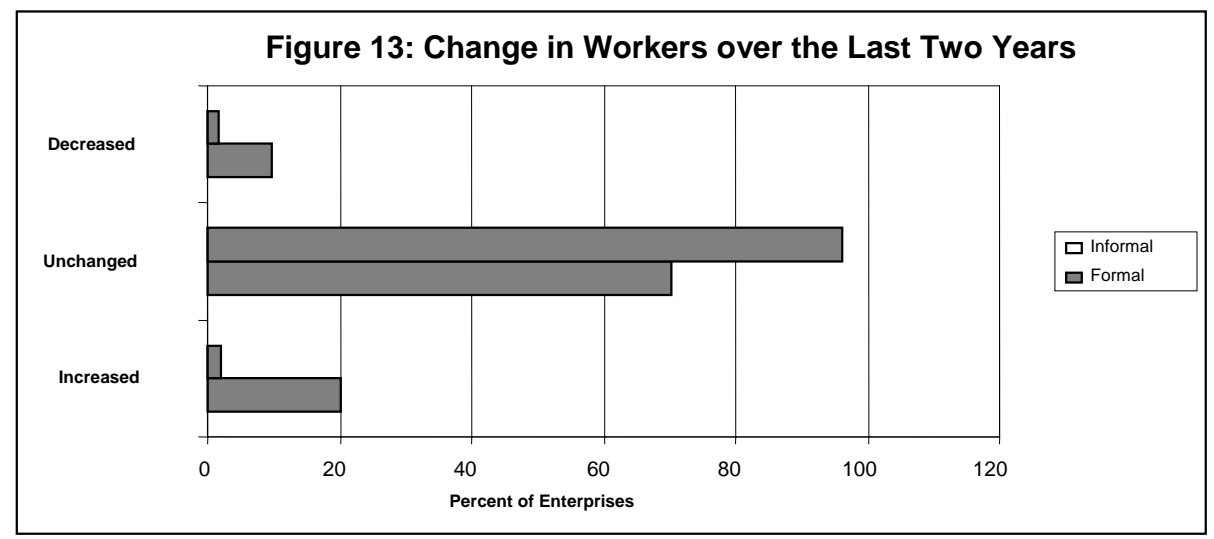

Source: UES, 2004.

35. Employers were also asked about their plans for hiring in the coming year. On this question, the answers of formal and informal sector employers show considerable divergence, with formal sector employers overwhelmingly indicating that they plan to hire, while informal establishments - which account for the large bulk of employment - for the most part remain uncertain about their hiring plans (see Table 6). Such uncertainty is not surprising given the various shocks to which urban Timorese labor markets have been exposed since the late 1990s. However, given the demographics of sustained net inflows to the labor force, the data on hiring plans gives cause for concern about the capacity of Timor to create employment for urban youth.

Table 6: Hiring Plans of Urban Enterprises for the Next Year in 2004

\begin{tabular}{|l|c|c|c|c|}
\hline & \multicolumn{2}{|c|}{ Formal } & \multicolumn{2}{c|}{ Informal } \\
\hline & $\mathrm{N}$ & Percent & $\mathrm{N}$ & Percent \\
\hline $\begin{array}{l}\text { Plans to hire the next year } \\
\text { (reporting yes) }\end{array}$ & 108 & 84.4 & 56 & 28.6 \\
\hline Don't know & 20 & 15.6 & 140 & 71.4 \\
\hline Total (Responded) & 128 & 100 & 196 & 100 \\
\hline \multicolumn{4}{|l}{} \\
\hline
\end{tabular}

36. (b) Hiring Practices in Urban Enterprises: In addition to hiring history/plans, the survey asked about preference in hiring between younger and older workers and recruiting methods.

37. (i) Age: The survey asked questions on perceptions of respondents (usually owners or managers) about hiring younger as compared to older workers. Concerns in Timor Leste about younger workers being less likely to get jobs are strong, and youth unemployment rates in urban areas are high. However, employers of both formal and informal employers overwhelmingly reported that they make no distinction based on age in hiring decisions (Figure 14). To the extent that they make a distinction, there is a preference for younger workers. These findings need to be interpreted cautiously given the lack of recent hiring, but are nonetheless of interest.

38. If there really is no age-based discrimination in hiring, and it is younger workers who dominate self-employment, further research needs to address both the macro and individual levels determinants of youth unemployment in Timor-Leste, which may be due to reasons of skill gaps, motivation, and other barriers to entry into the workforce. For example, emerging research indicates that it is more difficult for 15-24 youth group to find a paid job as compared to older 
groups aged between 25 and 54, controlling for individual characteristics. ${ }^{6}$ Another factor which warrants further research is on duration of youth unemployment. This is high in many countries, but is also often of short duration compared to older workers.

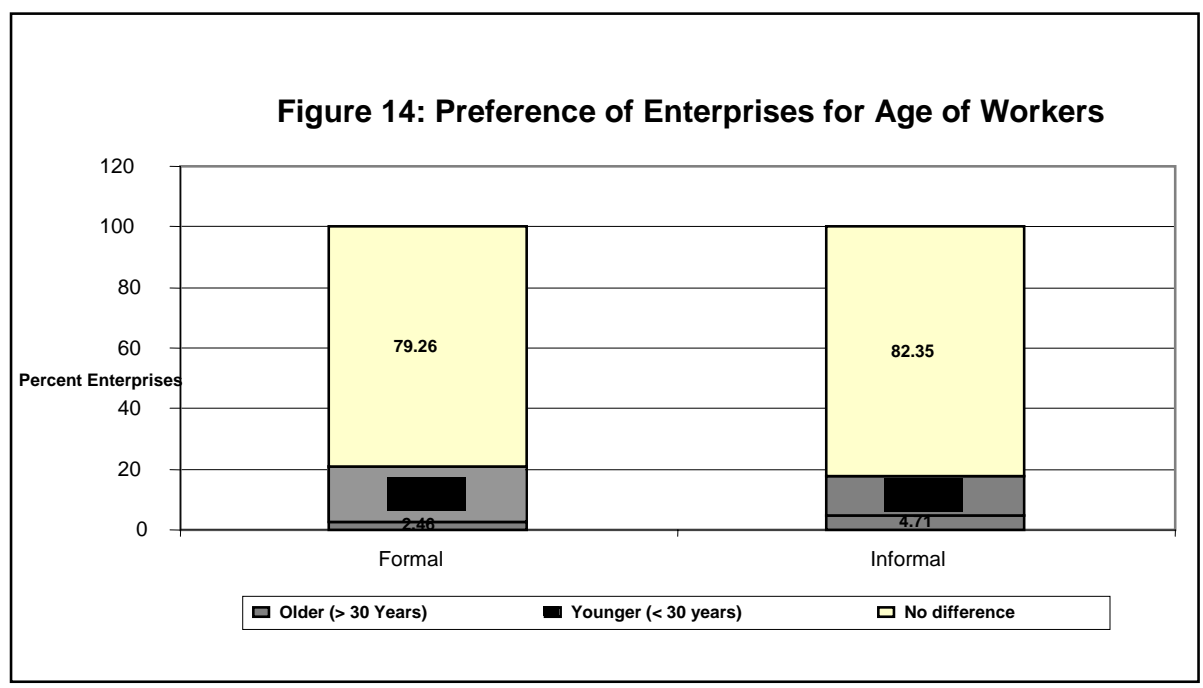

39. (ii) Recruiting Methods: Results of the survey indicate that the predominant source of recruiting employees is through informal means - family, friends, or word of mouth. Hardly any enterprises - formal or informal - use formal methods of hiring, again pointing to pervasive informality even in formal enterprises.

Table 7: Preferred hiring methods

\begin{tabular}{|l|c|c|}
\hline Hiring Method & \% of Formal & \% of Informal \\
\hline Consulting workers/family/friends/word of mouth & 75.9 & 94.6 \\
\hline Approaching educational institutions & 0.7 & 3.6 \\
\hline Advertising & 0.1 & 0.0 \\
\hline A combination of recruiting methods above & 0.1 & \\
\hline Other & 2.0 & 5.4 \\
\hline
\end{tabular}

Note - option of more than one method, and some enterprises failed to answer. Source: UES, 2004

40. (c) Startup Capital and Insights into Profitability: About one quarter of formal and almost 90 percent of informal firms have startup capital of less than USD 1,000 (Figure 15). This confirms the overall picture of very small enterprises, and greater similarities rather than differences between registered and unregistered (formal and informal) enterprises. Even the sources of startup capital indicate a remarkable degree of homogeneity among the two types of enterprises. Only about seven percent of either category use non-personal or family resources as startup capital, indicating that institutional sources are almost non-existent for the purposes for financing these ventures.

\footnotetext{
${ }^{6}$ See Nguyen and Subbarao (forthcoming) on youth in TL.
} 
Figure 15: Sources of Startup Capital

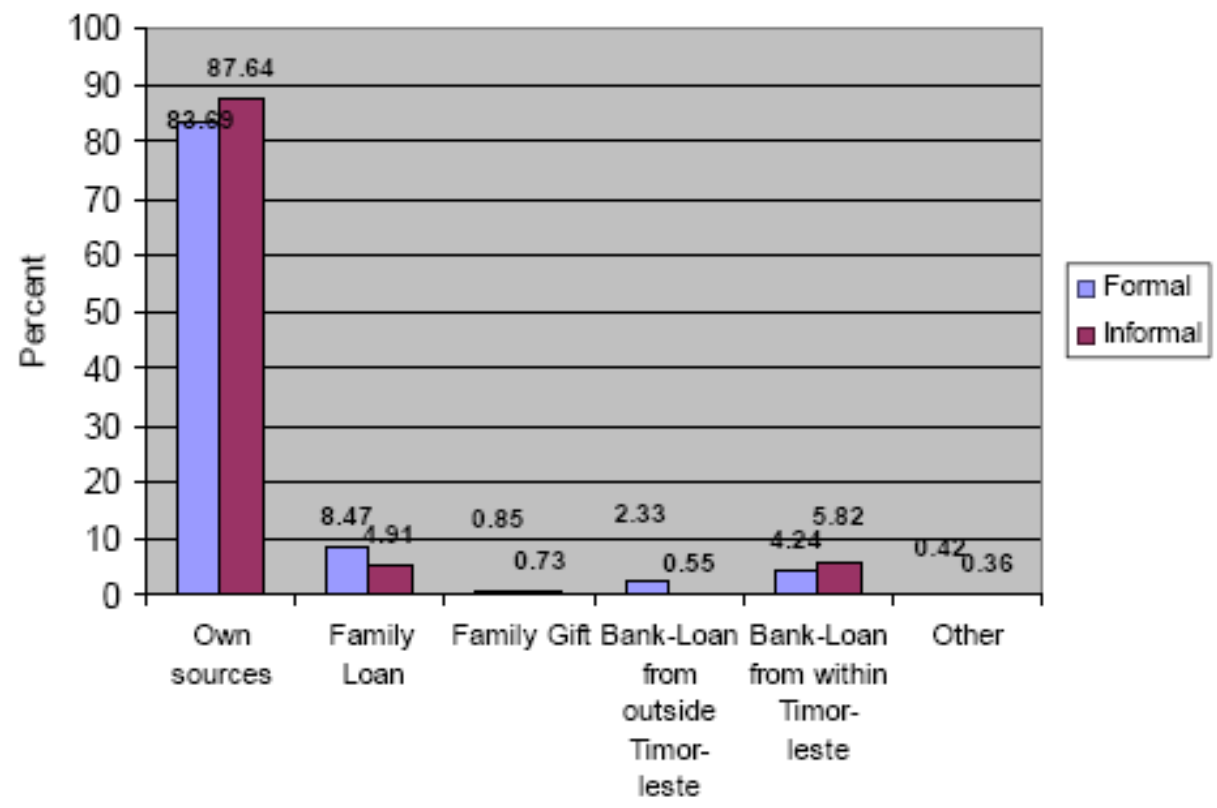

Source: UES, 2004

41. Of equal interest is the comparison of start-up capital and enterprise turnover (Figures 16 and 17). For formal enterprises, there is a fairly close correlation between start-up capital and annual turnover. Informal enterprises in contrast exhibit a larger gap between startup costs and annual turnover. While the data do not permit strong conclusions to be drawn, the numbers - particularly for the informal sector - point to significant possibilities for more active credit markets which deal in small loan amounts.

42.

Figure 16

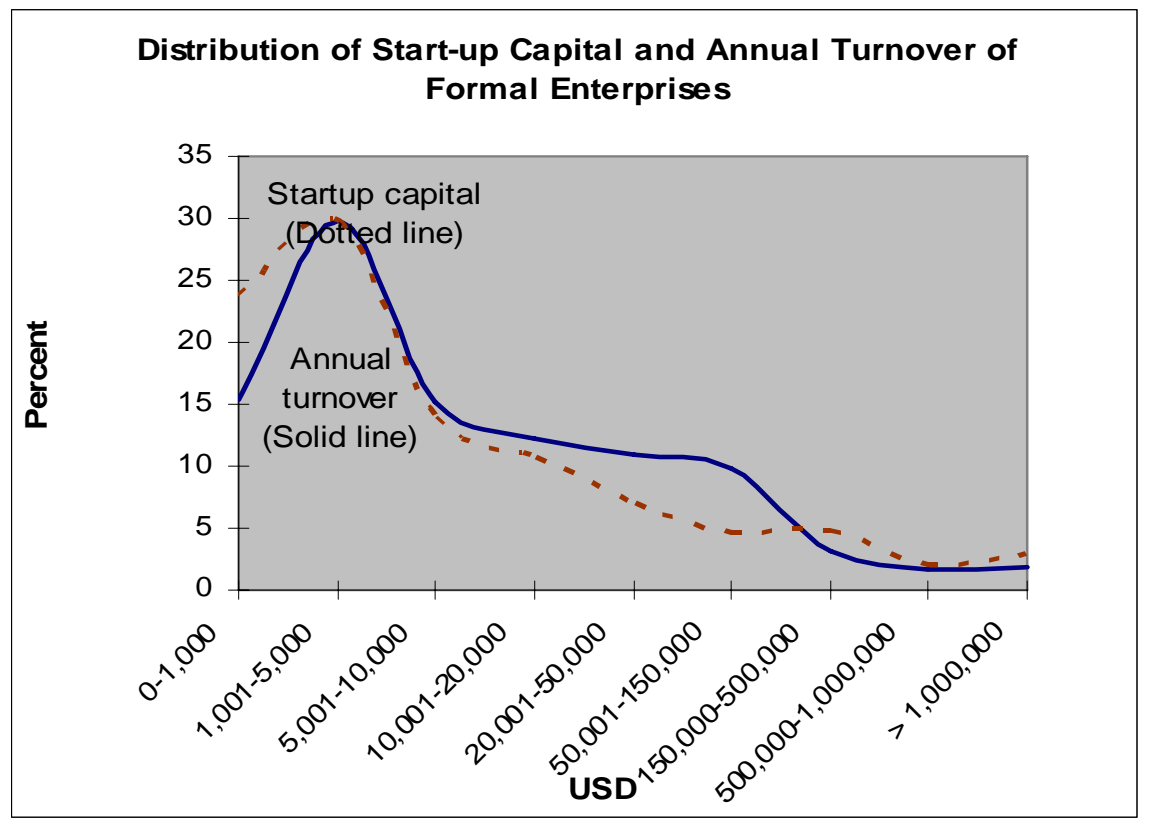

Source: UES, 2004 
42. (d) Barriers to growth: About 75 percent of formal and 81 percent of informal enterprises wanted to expand their business, and listed financial constraints as being the most daunting (see Table 10). Others were lack of adequate demand and (mainly for formal enterprises) lack of appropriate workers. The barrier of adequate financing indeed appears to be a key source of concern since, startup capital is overwhelmingly from private, non-institutional sources, for both types of enterprises. Underdeveloped credit markets - despite the impressive this growth in recent years - and lack of aggregate demand both appear to be barriers to firm growth. Given the different policy implications of the two, warrants further investigation.

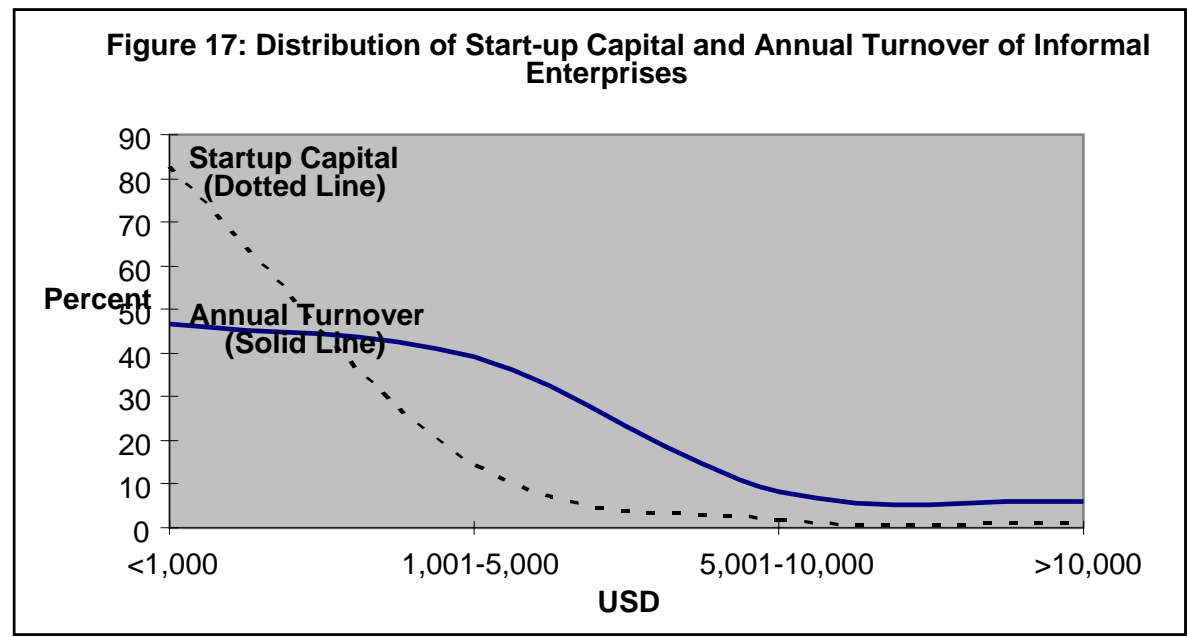

Source: UES, 2004

43. (e) Non-wage Benefits for Workers: The survey asked about several non-wage benefits (see Table 9). As might be expected, overall, there is significant divergence in non-wage benefits claimed to be provided between formal and informal enterprises. Employers in formal enterprises claim to provide more substantial benefits than would be expected of such small ventures. However, this picture of non-wage benefits in urban enterprises must be taken with an important caveat. Since the survey asks questions of owners and managers, they may well have tailored their responses in the context of the prevailing laws and procedures. Therefore, further research is needed before conclusive statements can be made.

Table 8: Constraints to Growth Reported by Urban Enterprises

\begin{tabular}{|l|c|c|}
\hline Constraint & $\begin{array}{l}\text { \% of Formal Enterprises } \\
\text { Reporting “yes” }\end{array}$ & $\begin{array}{l}\text { \% of Informal Enterprises } \\
\text { Reporting “yes” }\end{array}$ \\
\hline Financial & 60.1 & 81.0 \\
\hline Demand/Market & 38.1 & 40.0 \\
\hline Appropriate workers & 14.6 & 2.3 \\
\hline \multicolumn{2}{|l|}{ Note: Enterprises reported more than one constraint } \\
\hline
\end{tabular}

Source: UES, 2004

44. With this caveat, we find that less than half the formal enterprises give a written contract to their employees. A little over one-third give a contract to all their employees. Almost none of the informal enterprises provide a written contract and this is consistent with their "informal" status. This is not surprising given the findings presented in Section 1 on the time and costs of contract enforcement, but may also be a reflection of high levels of social capital in Timor-Leste. However, surprisingly, severance pay appears to be the norm among formal enterprises, as the large majority of them give severance pay to their employees. In fact only 7.5 percent of them do 
not provide severance pay to any of their employees. Among informal enterprises the reverse holds, with only about 7 percent providing any severance pay. Given the emerging structure of informality among enterprises - both formal and informal - in terms of contract, size, location, sector, and other aspects, the high prevalence of formal sector severance pay needs further analysis and understanding. Given the low turnover in employment seen earlier, it would appear that few employers have to date been required to fulfill their stated obligations on severance pay. The results therefore can perhaps be interpreted more as an indication of awareness among formal sector employers of their obligations to pay severance in case of dismissal rather than evidence of consistent severance payments already made.

45. Another surprising aspect of both types of enterprises is the unexpectedly high proportion that claim to provide health benefits. More than half the formal and almost 30 percent of informal enterprises provide health benefits to employees. Whether the responses include publicly provided health benefits is unclear, though the prior would be that they may do. Less surprising is the high prevalence of sick/other paid leave that the enterprises give to workers. This fact is often not at variance with informality within the enterprises, as owners can give informal sick leave, and have employees "make up" later. Thus, almost three-fourths of formal and over one-fourth of informal enterprises report giving sick/other leave to some employees.

Table 9: Urban Enterprises Reporting Non-Wage Benefits to Workers

\begin{tabular}{||l|r|r|r|r|r|r|r|r||}
\hline & \multicolumn{2}{|c|}{ Written Contract } & \multicolumn{2}{c|}{ Severance Pay } & \multicolumn{2}{c|}{ Health Benefits } & \multicolumn{2}{c|}{$\begin{array}{c}\text { Sick/Other Paid } \\
\text { Leave }\end{array}$} \\
\hline & Formal & Informal & Formal & Informal & Formal & Informal & Formal & \multicolumn{1}{c|}{ Informal } \\
\hline To all workers & 37.8 & 0.9 & 82.9 & 4.5 & 46.5 & 27.9 & 64.9 & 26.1 \\
\hline $\begin{array}{l}\text { To some of the } \\
\text { workers }\end{array}$ & 9.0 & 0.5 & 9.6 & 2.6 & 12.3 & 1.4 & 8.9 & 1.2 \\
\hline $\begin{array}{l}\text { To none of the } \\
\text { workers }\end{array}$ & 53.2 & 98.6 & 7.6 & 92.8 & 41.3 & 70.7 & 26.2 & 72.7 \\
\hline
\end{tabular}

Source: UES, 2004

46. For informal enterprises, payment in-kind represents a significant mode of compensation, as one might expect given the nature of the businesses, with over a third of establishments offering payment in-kind (see Table 12). Unfortunately, responses on payment in-kind questions were of questionable quality. Nonetheless, the broad ranking in order of importance of types of in-kind compensation appears to be food, clothing (both paid by the vast majority of establishments paying in-kind), education costs, and shelter.

Table 10: Payment in Kind Offered by Urban Informal Enterprises

\begin{tabular}{|l|l|l|}
\hline & \multicolumn{2}{|l|}{ Offer Payment in kind } \\
\hline & N & Percent \\
\hline Yes & 180 & 35.4 \\
\hline No & 329 & 64.6 \\
\hline Total & 509 & 100 \\
\hline
\end{tabular}

Source: UES, 2004

\section{(iii) Wages and Wage-Setting}

47. Little is known about the main factors which are taken into account in setting wages in Timor-Leste. Unions are still in their infancy and do not play a large role in wage-setting, with a few exceptions such as Dili port workers. There is an informal MW of USD 85, but no statutory wage setting mechanism to date. Thus, with the primary exception of the public sector, wages are 
set through bilateral negotiations between employers and employees on a highly decentralized basis. The survey results indicate that there is little difference in the basis on which wages are set between formal and informal enterprises. Wages are based first and foremost on the workers' skills, followed by experience and finally affordability of the enterprises (Figures 18 and 19). Other factors like age of worker and comparative wages appear to play a very small role, and workers’ demands play almost no role at all.

48. (a) Wage Levels: The survey asked about wages and non-wage payments for both formal and informal sector workers. Unfortunately, the quality of responses from informal sector establishments was so poor that the present report does not feel confident to report results. This is regrettable, given the dominance of the informal sector in employment. Nonetheless, some observations and inferences can be drawn from the formal sector wage information, which was considerably more reliable.

49. The average wage in urban areas in Timor Leste was USD 150 in $2001 .^{7}$ Results from the 2004 urban survey are only obliquely comparable to the 2001 TLSS, but in 2004, the average wage was USD 158 for urban formal enterprises. This suggests that average nominal wages have not risen at all in the aggregate, given that the 2001 figure includes both formal and informal sector urban workers. In addition, annual inflation rates in the intervening period were not insignificant, at 10 percent in 2001-02 and around 4 percent in the 2002-2004 period. It therefore seems safe to conclude that real wages in urban areas have fallen in the 2001-2004 period. The extent of the fall could be significant, but robust quantification will require better data on urban informal sector compensation.

50. A disaggregated comparison of wages between 2001 and 2004 is only partly possible. It is not possible to compare the average wages by occupational/skill category between the 2004 survey and the urban workers in TLSS. However, the average wage of professional workers, which includes technical, administrative, managerial workers, was USD 209 in the TLSS. If these workers are taken together in the 2004 urban survey, their average wage was USD 206 per month. If one takes the groups as reasonably comparable, this suggests that real wages for professional workers in urban areas have fallen by around 15 percent between 2001 and 2004.

Figure 18: Main factors in Wage-Setting Reported by Formal Enterprises

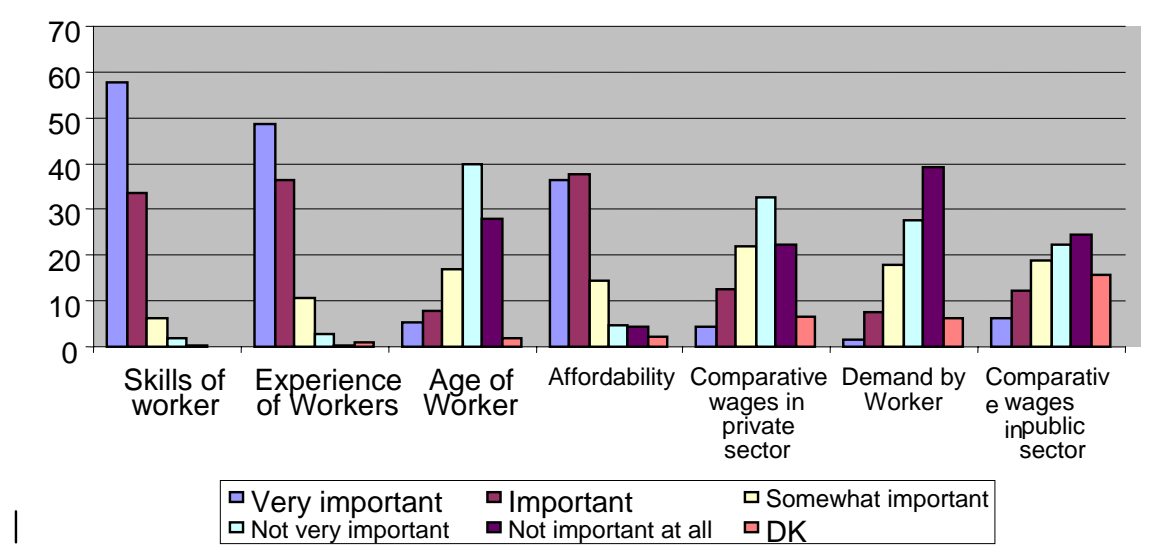

Source: UES, 2004

\footnotetext{
${ }^{7}$ See Das, 2004.
} 
51. The wage trajectory of lower skilled workers is challenging to piece together, due to more pronounced lack of comparability between the 2001 and 2004 surveys. In 2001, the lowest decile of urban workers earned a monthly average of USD 59, the lowest quintile a monthly average of USD 74, and the median urban worker earning USD 116. Unfortunately, it is possible reliably to compare only average wages in the urban formal sector in 2004 with these numbers. These can be seen in Table 11 below. Given the dominance of manual and service workers in employment, and the fact that Table 11 represents only the (presumably better-paid) formal sector, it seems safe to assume that the median wage in 2004 was below that of 2001.

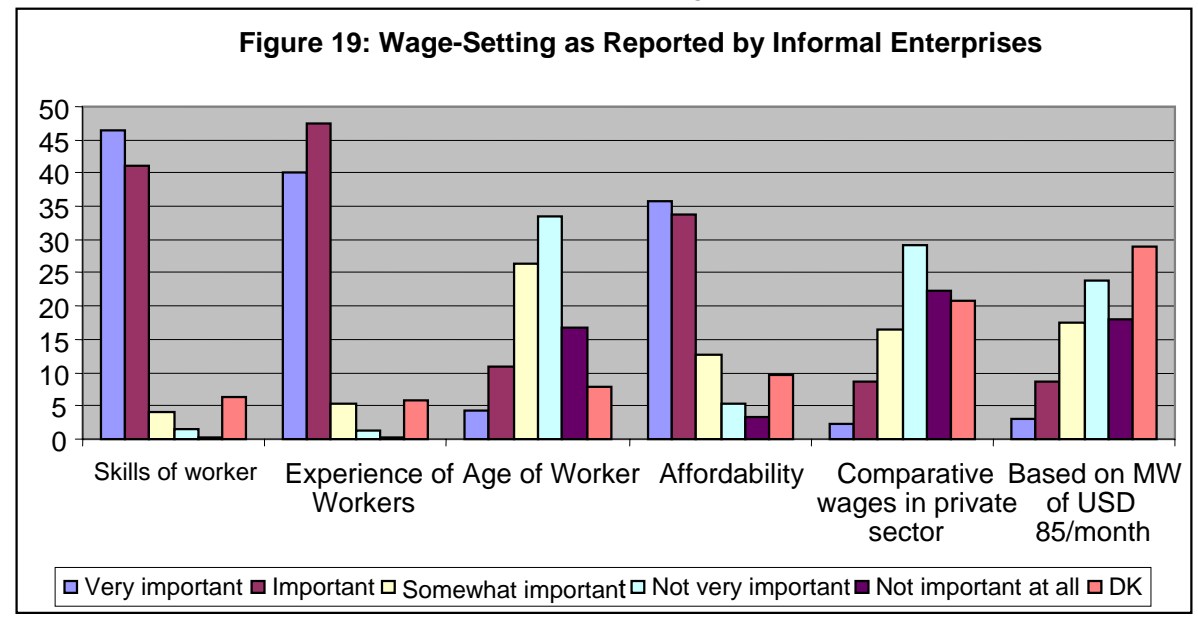

Source: UES, 2004

52. The survey also asked about wages for each urban area by category of worker and also overall by size of firm. The results need to be treated with caution, due to small cell sizes for some groups. However, some clear and apparently reliable patterns emerged. First, as one would expect, Dili had easily the highest wages across all categories of workers. Maliana and Baucau exhibit no consistent pattern of relative wages across worker categories, but this may be driven by small cell size.

53. As far as enterprise size and wages go, small and small/medium enterprises had the lowest and roughly similar average wage levels for manual workers, with a notable increase for medium sized enterprise manual employees and large enterprises paying the highest average wages for this group.

Table 11: Average Wages by Occupational Groups for Urban Formal Enterprises, 2000

\begin{tabular}{|l|c|}
\hline & Average Wages (USD/per month) \\
\hline Manual workers & 90.72 \\
\hline Service workers & 85.32 \\
\hline Administrative workers & 148.09 \\
\hline Technical and Professional workers & 187.70 \\
\hline Managerial workers & 282.93 \\
\hline
\end{tabular}

Source: TLSS, 2000.

54. In 2004, the range of wages for younger workers was lower than that for older workers (see Table 12). This in fact, may be related to why enterprises have no such preference. If younger workers come with less experience, but also command lower wages, one would not 
expect significant age discrimination in hiring. The argument for having a lower MW for younger workers as many countries have done is based on this fact.

Table 12: Range of Wages by Age in Urban Formal Enterprises, 2004

\begin{tabular}{|l|c|c|c|c|}
\hline & \multicolumn{2}{|c|}{ Average Minimum } & \multicolumn{2}{c|}{ Average Maximum } \\
\hline Age Category & $\mathbf{N}$ & USD/month & $\mathbf{N}$ & USD/Month \\
\hline $15-24$ & 177 & 78.26 & 145 & 109.73 \\
\hline $25-30$ & 212 & 94.67 & 186 & 148.98 \\
\hline $31-40$ & 138 & 128.30 & 149 & 194.40 \\
\hline $41-50$ & 58 & 177.03 & 74 & 239.86 \\
\hline Above 50 & 28 & 233.06 & 41 & 262.87 \\
\hline
\end{tabular}

Source: UES, 2004

55. (b) Importance of Minimum Wages in Timor Leste: The MW in Timor-Leste was informally set at USD 85 per month by UNTAET. While this has not been legally binding, it has had an important impact on wage setting in the formal sector, in particular the civil service. Box 1 lays out the situation in Timor Leste with respect to MW, with comparisons from other countries in the 1990s and 2000. Even using only formal sector data from the present survey, it is clear that the informal MW remains very high in terms of relativity to average urban wage in Timor Leste, being equal to the average wage for urban formal sector service workers and around 95 percent of the average wage for urban formal sector manual workers.

\section{Box 1: Informal Minimum Wage in Timor Leste in Comparative Perspective}

- In absolute terms, the informal MW for Timor-Leste is dramatically higher than the level of MW in countries of comparable income levels, including neighboring Indonesia and Vietnam. A MW level of USD 85 places Timor-Leste close to Uruguay in the 1990s. However, the per capita income of Uruguay was USD 6581 and the average years of schooling for its over-15 population was 7.56 in the 1990s, compared to USD 472 and 4.62 respectively for Timor-Leste.

- The informal MW/AW ratio for Timor-Leste on 2000 was 0.56 in urban areas, or in other words, the MW accounted for 56 percent of average wages. This put Timor-Leste ratio in the "very high" range in international comparison, higher than the Netherlands and Ukraine and closer to countries such as France.

- The monthly MW of West Nusa Tenggara in Indonesia was set at around USD 24 in 2001 and at USD 40 at the end of 2003. The informal MW of USD 85 per month for Timor-Leste is almost twice as high. While cost of living may also be higher in parts of Timor-Leste such as Dili due to heavy donor presence, these differentials between West Nusa Tenggara and Timor-Leste are likely to narrow over time.

- If average years of schooling is taken as a proxy of skill levels, Timor-Leste with average years of schooling of 4.62, is closer to the Dominican Republic, but the latter had a had a MW of USD 42 in the mid 1990s. Thus, even in terms of skill levels, Timor-Leste has high informal MW levels.

- Finally, in terms of per capita income, Timor-Leste is closer to Pakistan, which had a MW of USD 50 in the mid-1990s.

Source: Drawn from Das, 2004 (a).

56. A clearer picture of the potential impact of enforcing the currently informal MW emerges if we look at formal enterprises in a disaggregated manner. Firms were asked about the impact on future hiring and firing of enforcing USD95 MW. Figure 20 and Tables 13 to 15 show that the 
strongest impact of a formal and enforced MW of 85 per month would be felt by smaller enterprises (which employ the bulk of self-employed persons), and enterprises outside Dili. Finally, those enterprises that would be most adversely affected by a MW of USD 85 per month that was enforced would be the ones owned by Timorese, rather than foreign or joint venture firms. Thus, the majority of the informal firms (63 percent) and a substantial chunk of formal firms (40 percent) would be adversely affected (in terms of not growing due to the MW), and this could have very negative effects on future employment in a labor market where there will be increasing cohorts of youth entering the labor force.

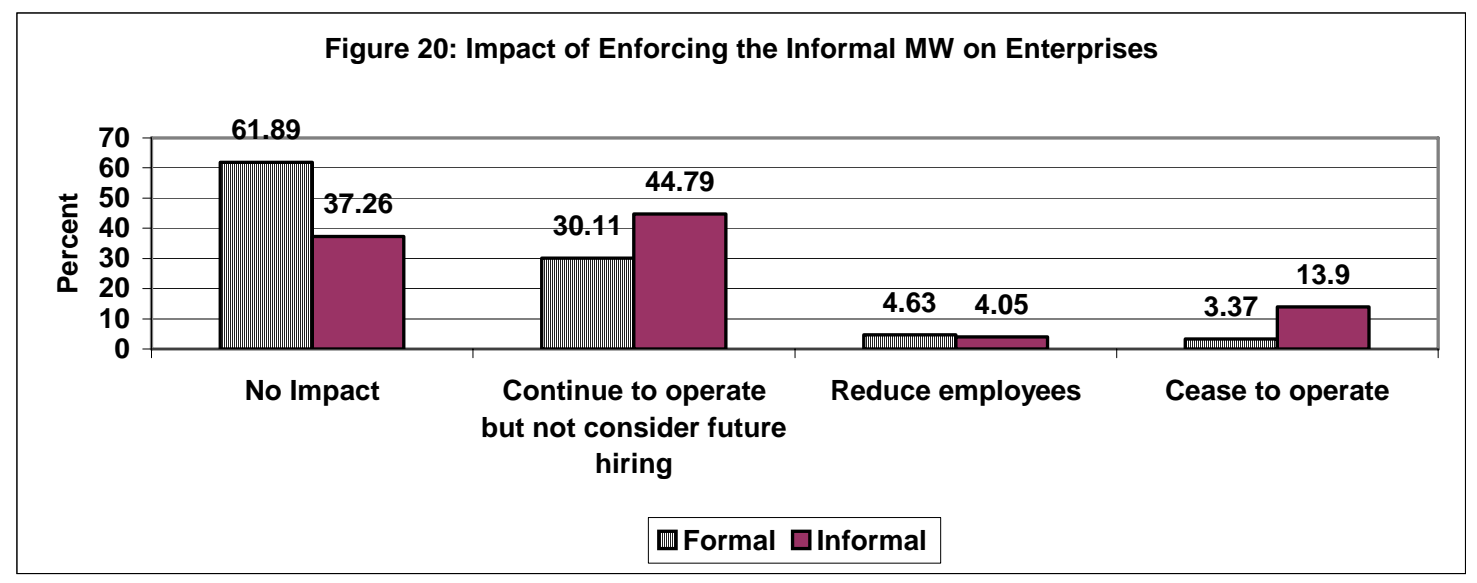

Source: UES, 2004

Table 13: Impact of Enforcing USD 85 MW on formal enterprises by Annual Turnover (\% of firms)

\begin{tabular}{||l|c|c|c|c||}
\hline & No Impact & $\begin{array}{l}\text { Continue to operate but not } \\
\text { consider future hiring }\end{array}$ & $\begin{array}{l}\text { Reduce } \\
\text { employees }\end{array}$ & $\begin{array}{l}\text { Cease to } \\
\text { operate }\end{array}$ \\
\hline $\begin{array}{l}\text { Micro } \\
(<1000 \text { USD) }\end{array}$ & 46.5 & 38.0 & 5.6 & 9.9 \\
\hline $\begin{array}{l}\text { Small } \\
(1000-10000 \text { USD) }\end{array}$ & 58.2 & 32.9 & 5.2 & 3.8 \\
\hline $\begin{array}{l}\text { Small-medium } \\
(10000-20000 \text { USD) }\end{array}$ & 67.9 & 21.4 & 10.7 & 0 \\
\hline $\begin{array}{l}\text { Medium } \\
(20000-50000 \text { USD) }\end{array}$ & 67.9 & 30.2 & 1.9 & 0 \\
\hline $\begin{array}{l}\text { Large } \\
(>50000 \text { USD })\end{array}$ & 76.1 & 21.6 & 1.1 & 1.1 \\
\hline \hline
\end{tabular}

Source: UES, 2004

Table 14: Impact of Enforcing USD 85 MW on formal enterprises by number of employees (\% of workers)

\begin{tabular}{||l|c|c|c|c||}
\hline & No Impact & $\begin{array}{l}\text { Continue to operate but not } \\
\text { consider future hiring }\end{array}$ & $\begin{array}{l}\text { Reduce } \\
\text { employees }\end{array}$ & $\begin{array}{l}\text { Cease to } \\
\text { operate }\end{array}$ \\
\hline $\begin{array}{l}\text { Small employers } \\
(<10 \text { workers) }\end{array}$ & 57.4 & 33.3 & 5.2 & 4.1 \\
\hline $\begin{array}{l}\text { Medium employers } \\
(10-20 \text { workers) }\end{array}$ & 76.1 & 19.6 & 2.2 & 2.2 \\
\hline $\begin{array}{l}\text { Large employers } \\
(>20 \text { workers })\end{array}$ & 68.2 & 25 & 6.8 & 0 \\
\hline
\end{tabular}

Source: UES, 2004 
Table 15: Impact of Enforcing USD 85 MW on formal enterprises by Urban Area (\% of firms)

\begin{tabular}{|l|c|c|c|c|}
\hline & No Impact & $\begin{array}{l}\text { Continue to operate but not } \\
\text { consider future hiring }\end{array}$ & $\begin{array}{l}\text { Reduce } \\
\text { employees }\end{array}$ & Cease to operate \\
\hline Maliana el. Bobonora & 52.5 & 35 & 7.5 & 5 \\
\hline Baucau & 46.4 & 40 & 5.5 & 8.2 \\
\hline Dili & 69.1 & 24.9 & 4.4 & 1.6 \\
\hline
\end{tabular}

Source: UES, 2004

\section{(iv) Training and Skills in the Urban Labor Market}

57. Skills gaps among workers in Timor-Leste have been a prominent subject in the national discourse. In order to elicit information on the scale and nature of the gaps, the survey asked formal enterprises (only) to report on the skills of their employees and training they had received $^{8}$. It also asked about perceived skills gaps in the current workforce and demand for skills among employers.

58. (a) Skills status and gaps: Employers reported that in each category of workers (manual, service, administrative, technical), except managerial, less than half of workers were fully proficient in their jobs. Managerial workers appear to be the most proficient, and 72 percent of firms reported the managerial category to be fully skilled in their jobs. Enterprises also reported that the categories most likely to have skill gaps (i.e. having no workers that were fully proficient) were administrative (12 percent) and technical/professional (21 percent). In spite of the fact that about half the workers in each category are fully proficient (and another 20-30 percent are almost proficient), enterprises also identified major gaps for each category of workers (Table 16).

59. Across all categories of workers, English and Portuguese language skills were identified as the single most important skill gap. Manual workers need a range of skills, the most important of which appear to be language, technical and practical skills, and basic numeracy/literacy. The most significant skill gaps for service workers seem to be language, customer handling skills, and administrative and financial skills. In the case of administrative workers, enterprises report them as being most deficient in administrative and financial and language skills. Technical and professional workers appear to need language and technical/practical skills, while managerial workers need to hone language skills most, but also their management, administrative, marketing, and negotiating skills. Clearly therefore, language skills and technical skills appear to be the most lacking among workers of formal enterprises.

60. Employers were further probed on what skills they expected to become more important in the coming two years, as some indication of emerging areas of labor demand. The main areas are listed in Table 17 below. As can be seen, one significant group of skills (i.e. literacy, numeracy and problem solving) are skills that in principle should be being provided through the general education system and hence have policy implications for that sector. Others, such as driving or customer handling, are skills which typically are provided in the private sector or on-the-job training. Others need further assessment of the extent to which public sector and private sector training providers are meeting demand.

\footnotetext{
${ }^{8}$ It was planned to ask the same questions of informal establishments, but pilot testing revealed that there were insufficient reliable answers.
} 
Table 16: Skill Gaps of Workers by Category in Formal Enterprises

\begin{tabular}{|c|c|c|c|c|c|}
\hline $\begin{array}{l}\text { Type of Skill Missing Among } \\
\text { Current Employees }\end{array}$ & $\begin{array}{l}\text { Manual } \\
\text { workers }\end{array}$ & $\begin{array}{l}\text { Service } \\
\text { workers }\end{array}$ & $\begin{array}{c}\text { Admin } \\
\text { workers }\end{array}$ & $\begin{array}{c}\text { Technical and } \\
\text { professional } \\
\text { workers } \\
\end{array}$ & $\begin{array}{c}\text { Managerial } \\
\text { workers }\end{array}$ \\
\hline Numeracy skills & 15.2 & 15.6 & 8.5 & 4.1 & 8.1 \\
\hline Literacy skills & 10.7 & 12.2 & 2.2 & 1.2 & 4.1 \\
\hline Language (English/Portugese) & 46.6 & 57.7 & 33.4 & 21.5 & 57.9 \\
\hline Technical and practical & 21.3 & 14.4 & 3.9 & 14.4 & 6.5 \\
\hline Customer handling skills & 16.2 & 34.8 & 8.5 & 2.4 & 12.6 \\
\hline Management skills & 7.7 & 11.1 & 14.8 & 2.0 & 28.5 \\
\hline Administrative \& Financial & 12.0 & 20.9 & 39.3 & 4.9 & 27.1 \\
\hline Driving skills & 11.1 & 10.1 & 3.9 & 3.2 & 5.1 \\
\hline Basic computer literacy skills & 10.9 & 14.2 & 14.2 & 7.7 & 17.6 \\
\hline Advanced IT or software skills & 7.5 & 10.3 & 10.3 & 8.9 & 13.6 \\
\hline Marketing skills & 7.5 & 13.8 & 9.3 & 3.6 & 22.7 \\
\hline Negotiating skills & 6.1 & 12.4 & 6.9 & 3.0 & 25.9 \\
\hline No need to acquire further skills & 3.8 & 3.9 & 1.6 & 2.2 & 8.1 \\
\hline
\end{tabular}

Note: More than one skill reported. Source: UES, 2004

61. From a public policy viewpoint, the above results need to be assessed carefully. Not all the needed skills listed are ones that need to be provided by the public sector. Some skills (e.g. driving) are generally provided through private channels quite effectively. There is clearly a need for assessing where the market failures on skills training are most pronounced in order to assess implications for future training policies.

Table 17: Skills to be become important in next 2 years

\begin{tabular}{|l|c|}
\hline \multicolumn{1}{|c|}{ Skill } & Percent Enterprises \\
\hline Customer handling & 61.9 \\
\hline Driving & 57.9 \\
\hline Problem solving & 44.5 \\
\hline Advanced IT or software & 41.9 \\
\hline Technical and practical & 38.5 \\
\hline Literacy & 32.2 \\
\hline Numeracy & 30.4 \\
\hline Communication & 29.8 \\
\hline Foreign Language & 24.9 \\
\hline Basic computer literacy & 23.8 \\
\hline Teamwork & 18.6 \\
\hline Other & 5.3 \\
\hline
\end{tabular}

Note: More than one skill reported. Source: UES, 2004.

62. (b) Training provision: Almost 40 percent of the formal enterprises provide some training to their workers. A large part of this training is in-house and on-the-job, but a good 40 percent of the enterprises use external providers as well, either solely or in combination with other methods. The findings are presented in Figure 21 below.

\footnotetext{
${ }^{9}$ See Annex 4 for description of skills.
} 


\section{Figure 21: Type of Training Provided by Urban Formal \\ Enterprises to Employees}

(Note: Of the $40 \%$ which reported providing some training)

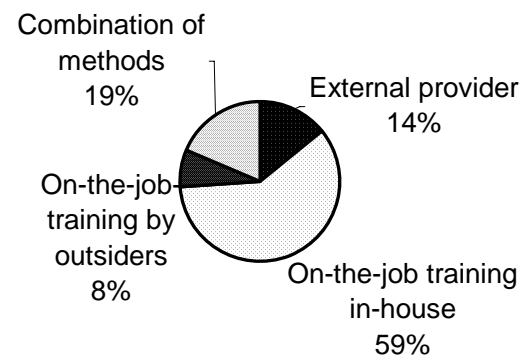

Source: UES, 2004

63. (c) Type of Training Institutions Most Valued: The survey results indicate clearly that employers do not value any of the formal training institutions highly in Timor Leste, with even the best rated institutions (short course technical) valued highly by less than 40 percent of formal sector employers. Nonetheless, in relative terms, there are clear differences in the value placed on different types of training institutions. While hiring their employees, formal enterprises appear to value most highly the training their employees receive through short technical courses (Figure 22). Second in order of preference are the skills acquired at SLTA, followed by technical and vocational training centers and STM/High schools. Surprisingly, school education (at the high school level) ranks higher than polytechnics. In fact, only 17 percent employers reported that they consider Indonesian universities and polytechnics as important, and this figure was even lower for Timorese polytechnics (less than 10 percent).

64. The majority of enterprises also reported that they would welcome a standard certification system for different skills. This is an area where the Government has recognized a need and a draft law establishing a national training authority, which would be responsible for development of a certification system, is under consideration. With respect to certification, there has already been considerable work done by consultants to both the former L\&S Secretariat and former MoEYCS which could inform the authority's work.

65. The above results strongly suggest that it is difficult to justify the existing 3 year formal training courses in both post-school and technical high school settings, given that they appear to be so poorly valued by employers and that the unit costs of provision to the budget are high. Better labor market outcomes would appear to be achievable at considerably lower cost in many cases through increased reliance on shorter courses, often offered through non-formal institutions. To the extent that longer course are required, the result suggest a need to explore consolidation options for institutions or possibly seeking to send trainees abroad. These findings are consistent with earlier technical reports on the TVET sector in Timor Leste. ${ }^{10}$

${ }^{10}$ See Abrahart, 2003 and 2004. 
Figure 22: Timor-Leste: Training/Insitution Valued by Employers of Formal Enterprises While Hiring

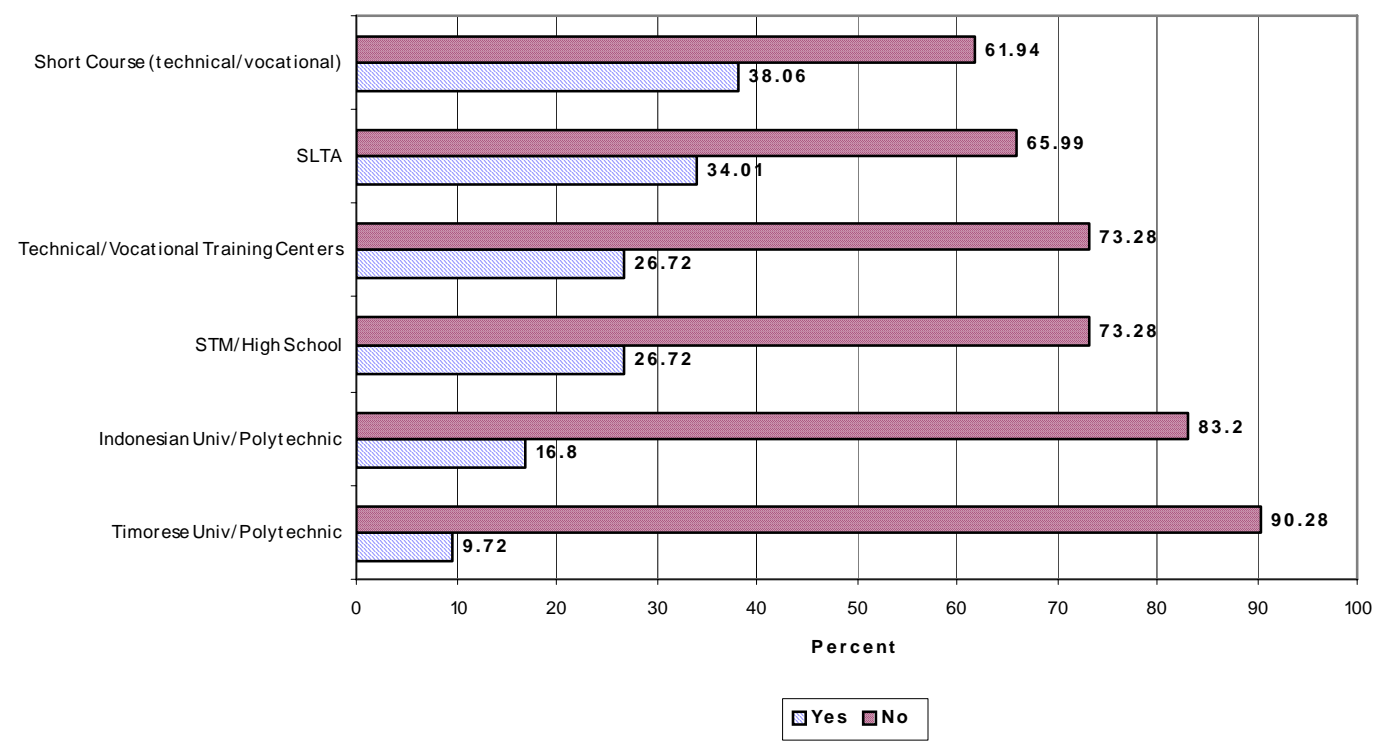

Source: UES, 2004

66. (d) Barriers to the Development of a Skilled Workforce: The survey contained a question on factors that constrain enterprises in maintaining a fully proficient work force. Supply side factors dominate among the constraints to developing a trained workforce for formal enterprises (Table 18). The constraints seem to be most daunting for manual, service and technical workers. Lack of funding is a common theme for each category of workers. However, in the case of manual and service workers, and less so for technical/professional and administrative workers, there also appears to a serious dearth of suitable courses and training organizations. Employers also think that in comparison with managerial and administrative workers, manual and service workers come into the firm with low qualifications. On the other hand, time constraints do not appear to be significant, indicating that if funding and appropriate training were available, workers would have the time to undertake training.

Table 18: Factors constraining development of proficient workers - formal enterprises

\begin{tabular}{|l|c|c|c|c|c|}
\hline & $\begin{array}{c}\text { Manual } \\
\text { workers }\end{array}$ & $\begin{array}{c}\text { Service } \\
\text { workers }\end{array}$ & $\begin{array}{c}\text { Admin } \\
\text { workers }\end{array}$ & $\begin{array}{c}\text { Tech/ profess } \\
\text { workers }\end{array}$ & $\begin{array}{c}\text { Managerial } \\
\text { workers }\end{array}$ \\
\hline Lack of funding & 25.9 & 24.3 & 10.9 & 15.8 & 35.8 \\
\hline Lack of qualified workers & 25.1 & 22.5 & 10.1 & 12.4 & 6.9 \\
\hline $\begin{array}{l}\text { Lack of suitable courses relevant } \\
\text { to upgrade the staff }\end{array}$ & 24.9 & 21.7 & 13.8 & 10.7 & 10.9 \\
\hline $\begin{array}{l}\text { Lack of appropriate training } \\
\text { organizations }\end{array}$ & 16.4 & 19.2 & 10.1 & 9.5 & 8.9 \\
\hline $\begin{array}{l}\text { Lack of knowledge of training } \\
\text { providers }\end{array}$ & 11.5 & 11.5 & 6.9 & 8.5 & 7.7 \\
\hline Lack of time for training & 13.4 & 11.5 & 6.7 & 7.5 & 14.8 \\
\hline
\end{tabular}

Source: UES, 2004 
67. (e) Relevance of Government Sponsored Institutions: It is clear from the above that labor market institutions are still developing in TL. The Government is keen to strengthen these and to improve mechanisms for training, facilitation of employment, tribunals and other institutions. The main point of interface between government-run institutions and employers is the Ministry of Labor and Community Reinsertion and its training and recruitment arm. The survey asked employers about the Employment Centers for Skills Development operated by the then Secretariat (now Ministry) and its relevance to them for training and recruitment of their employees. Only 30 percent of the formal enterprises knew about the public Employment Centers, and only half of those that were aware had actually had any contact with an employment center (see Figure 23). Even more notably, only eight firms (i.e. less than 2 percent of all formal enterprises) had undertaken any recruitment through the centre. Such low awareness and usage is in part a product of the young age of the centre. However, the results suggest a need to monitor closely if the situation improves over time and the implications for an employment centre-based approach to employment services.

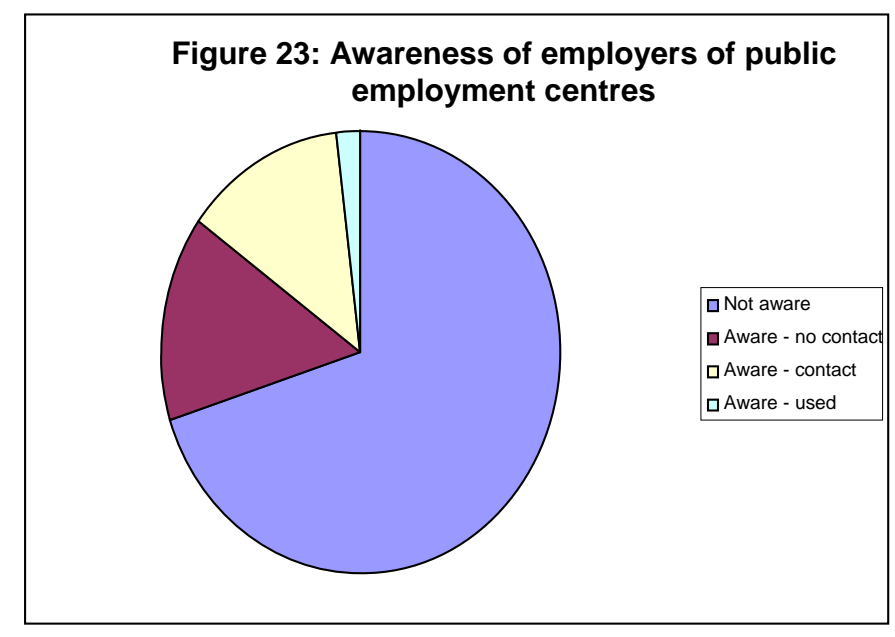

Source: UES, 2004

\section{Conclusions and Policy Implications}

68. Several observations on the environment for employment creation in Timor-Leste emerge from the survey and other evidence. The major points can be summarized as follows:

- $\quad$ Timor-Leste has undergone major macroeconomic fluctuations in recent years which would have challenged even the most resilient economy to sustain job growth. Despite prudent fiscal management, the demand shocks of 2002 and 2003 are likely to be important drivers of employment outcomes. In addition to shocks, TL's low state of economic development also creates a range of challenges for job creation, particularly in the formal sector.

- In the face of such macro and structural challenges, the business environment is less conducive than it could be to creation of good quality jobs in TL. The most negative feature is the high monetary and time costs of contract enforcement, but other elements such as the time and costs of business start-up and the difficulty of hiring workers in labour regulations are also likely to retard job growth. 
- $\quad$ By any standard, both formal and informal sectors in urban areas can for the most part be described as micro-enterprises. This applies to size of workforce (with less than 1 percent of firms having more than 10 workers), turnover ( 45 percent of formal and 86 percent of informal enterprises having turnover of less than USD 5,000), and startup capital (onequarter of formal and almost 90 percent of informal firms having startup capital of less than USD 1,000).

- $\quad$ Trading activities dominate at all firm sizes, and in both formal and informal sectors. Another important sector is construction, though it remains to be seen whether this persists as reconstruction needs and donor presence diminish.

- $\quad$ Consistent with their small size, only a minority of Timorese urban firms have a place of work outside the home. This applies to both informal (with only a quarter of firms having a formal place of business) and formal sectors (where only around 38 percent of firms do).

- The decline in formal sector establishments in 2003 and 2004 is a cause for concern, particularly as it has been the only (though small) source of net growth in recent years.

- The informal sector appears to be virtually stagnant in terms of hiring and firing, with neither creation nor destruction in recent years. While such a pattern has positive stability impacts in the short run, it risks being destabilizing in the long run in the face of large-scale inflows to the urban labour force. Given that worker turnover is also a significant source of productivity growth internationally, it also means that one important source of productivity growth is missing. Informal sector firms also exhibit high uncertainty on hiring plans for the future.

- In both formal and informal sectors, there is a willingness to hire younger workers, provided their skills are appropriate. However, this willingness is probably driven in significant measure by the lower ages they are paid.

- $\quad$ Recruitment in both sectors happens on a highly informal basis. This may have significant implications for public employment promotion efforts.

- Institutional sources of capital for business are negligible and shortage of credit is considered the single most important constraint on urban firms. At the same time, the low start-up costs of firms suggest that there is a major and under-exploited market for smallscale credit. At the same time, lack of demand was also identified as a major constraint, suggesting a need for more careful analysis.

- $\quad$ Real urban wages have almost certainly fallen noticeably in the period 2001-2004. While precise quantification is difficult, the wages of urban professional workers have probably fallen by around 15 percent in real terms in the period, and that real informal sector pay has probably also fallen (though more work is needed on the latter in particular).

- $\quad$ The informal MW in urban areas remains very high by any benchmark. Furthermore, firms indicate that efforts to formalize and enforce the current informal MW would have significant negative consequences on future hiring, with the effects more pronounced for very small enterprises which employ the bulk of urban workers. 
- $\quad$ There are significant skills gaps in the urban labor force. A number of these are skills best provided by the general education system and in some cases, the private sector. It would be important not simply to assume that the public post-general education system is the appropriate vehicle for skills development.

- $\quad$ Training of workers is happening, both in-house and by external suppliers. At the same time, employers have low confidence in existing training providers, most notably polytechnics and schools and training institutions which rely on long-course training.

- $\quad$ Firms identify primarily supply-side factors as major barriers to development of a more skilled workforce. Funding of training is, however, an issue. The introduction of an appropriate training accreditation and certification system is a clear need of firms.

69. A number of recommendations emerge from the snapshot of the urban labor market in Timor-Leste provided by the UES. They include:

- $\quad$ There are several elements of the broader business environment which would benefit from further reform if Timor Leste is to attract domestic and foreign investment beyond the petroleum industry, which can in turn promote employment growth. Such reforms can not single-handedly solve broader challenges of economic backwardness nor insulate the labor market from exogenous shocks, but they can play a significant role at the margin in maximizing employment growth given the initial conditions and emerging shocks. These relate to contract enforcement, provisions in labor regulations for hiring of workers, and the costs of starting a business. Not only are such onerous provisions likely to impinge directly on employment growth in the formal sector, but they also risk encouraging rent seeking by officials responsible for their enforcement.

- $\quad$ Further research on the urban labor market would be useful. While the UES is a useful first step, serious informational gaps remain, in particular on informal sector wage structure and trends. It would also be desirable to explore the interactions between urban and rural labor markets, in particular seasonal flows between them and whether inflows to urban labor markets are becoming more permanent over time, or alternatively weakening in the face of donor withdrawal from Dili.

- $\quad$ Any moves to formalize a minimum wage for Timor-Leste would benefit from more benchmarking of local wage levels and those of neighboring countries. The current informal MW is high and is not an advisable starting point. A MW at 50-60 percent of average wage is very high by international standards (see Table 20), as is the absolute value of the informal MW relative to countries at TL's level of per capita income. ${ }^{11}$ In addition, current wage patterns, the demographics of the urban labor market and international practice suggest that a youth minimum wage could be considered if a formal MW is introduced. International evidence indicates that high minimum wages can have negative impacts on employment generation for young people, and Timor Leste has a clear need with its demographic structure to promote a wage policy that facilitates to the maximum extent possible job growth for young people.

\footnotetext{
${ }^{11}$ Details on international comparators are provided in relation toTimor Lestein Das, 2004.
} 
Table 19: Categorization of minimum wage levels internationally

\begin{tabular}{|l|c|}
\hline \multicolumn{1}{|c|}{ Minimum wage level } & MW as percentage of average wage \\
\hline Low & Less than $20 \%$ \\
\hline Modest & $20-29 \%$ \\
\hline Medium High & $30-39 \%$ \\
\hline High & $40-49 \%$ \\
\hline Very High & $50 \%$ or more \\
\hline
\end{tabular}

Source: Rutkowski, 2003.

- Further deepening of credit initiatives would be beneficial in the face of widespread demand and relatively limited start-up financing needs. While progress has been made, the "missing middle" of credit markets in Timor Leste will continue to constrain the ability of firms to grow and generate the additional employment that is needed in urban areas of the country. The capacity for deepening credit markets will depend in part on a strengthened environment for contract enforcement, which is a key element of building the confidence of credit providers to expand coverage.

- $\quad$ Skills enhancement is widely acknowledged as a need at the micro and macro-levels. Higher skills in the workforce are critical to achieving higher productivity, which would in turn stimulate growth and employment opportunities. However, the lack of confidence in the current public training system suggests that a successful strategy would comprise several elements, with a strong role for the private sector. Suggestions which the UES and other work suggest include:

Public sector training could be strengthened through a greater emphasis on short courses, which are the ones most demanded by employers. Current long courses appear not to be achieving skills improvement to an extent that would justify their high unit costs.

- A common accreditation and certification system for training providers would be beneficial. There has been significant preparatory work in this regard, and it is a clear demand from employers.

Involvement of the private sector in both the development of the accreditation system and in development of training curricula would pay dividends in terms of improving skills matching in the country.

Consideration could be given to piloting demand-side interventions to those seeking to upgrade their skills. 


\section{Bibliography}

Abrahart, Alan (2003a): International Experience in technical and Vocational Education and Training (mimeo prepared for World Bank, available upon request).

(2003b): Timor Leste: Review of Technical and Vocational Education and Training and Employment Centres (World Bank consultant report, available upon request)

Das, Maitreyi (2004): The Labor Market Impact of Minimum Wage Policy: The Case of Timor-Leste in Comparative Perspective (World Bank mimeo).

Nguyen, Nga Nguyet, and Subbarao, Kalanidhi (forthcoming): Timor-Leste’s Youth Profile (draft mimeo, World Bank).

Rutkowski, Jan (2003): Minimum Wage Policy in International Perspective (mimeo, World Bank).

Wichmann, Jakob Mathias (2003): The Construction Sector in Timor-Leste: Results from a Rapid Survey (World Bank mimeo). 


\section{Annex 1: Sampling and survey documentation for Timor Leste Urban Enterprises Survey ${ }^{12}$}

1. This annex presents the sampling method used for the labour market survey supported by the Secretariat of Labour and Solidarity, the World Bank and the Government of Denmark and carried out by Dili Institute of Technology in 2004.

\section{Sample size and analytical domains}

2. The total sample size was estimated to be 950 enterprises, of which approximately 475 were formal enterprises and approximately 475 are informal enterprises. The formal businesses are sampled via the business register of Timor Leste.

3. With respect to informal businesses, a survey of households was conducted to locate the informal businesses through the households. Not all households have informal businesses - an estimate is that probably one third of households own or control some sort of informal business. Thus 1,425 households were to be visited to identify with 475 informal businesses.

4. The sample size of 900 businesses is sufficient to compare the formal and informal sectors. The sample size however does not allow detailed indicators of different industries in the of the labour market, which would require a larger sample size. Nonetheless, the survey provides independent estimates for certain policy relevant subgroups of businesses.

5. The analytical domains that are identified in this regard are the Major urban centres where businesses are present, that is, the city of Dili in which a majority of the businesses are placed, and Baucau and Maliana, the second and third largest cities of Timor-Leste. Moreover the cities geographically represent the West (Maliana), Centre (Dili) and East (Baucau) of TimorLeste. The key analytical domains of the sampling are presented in Table 1 below:

Table 1: Key analytical domains and expected responses

\begin{tabular}{|c|c|c|c|}
\hline & Dili & $\begin{array}{c}\text { Other urban } \\
\text { centres (Baucau, } \\
\text { Maliana) }\end{array}$ & Total \\
\hline $\begin{array}{c}\text { Informal } \\
\text { enterprises } \\
\text { (sample of } \\
\text { households) }\end{array}$ & 295 & 180 & 475 \\
\hline $\begin{array}{c}\text { Formal } \\
\text { enterprises } \\
\text { (sample of } \\
\text { business register) }\end{array}$ & 385 & $\mathbf{9 0}$ & 475 \\
\hline Total & $\mathbf{6 6 0}$ & $\mathbf{2 9 0}$ & $\mathbf{9 5 0}$ \\
\hline
\end{tabular}

6. The following sections describe the sampling strategies for the formal and informal sector respectively, but before that it necessary to give operational definitions to the concept presented in Table 1.

\footnotetext{
${ }^{12}$ This annex was prepared by Jakob Mathias Wichmann.
} 
7. Dili and Other urban centres represent a key distinction in that for example differences in salary levels can be expected due to the large representation in donors in Dili, and Dili being the financial centre with many registered enterprises. Table 2 below shows the operational distinction between the analytical domains, that is, Dili represented by urban sucos of the Dili district and other urban centres represented by the Baucau and Maliana.

8. As presented in Table 1 the other key distinction between formal and informal enterprises is operationalized as the dividing line between registered enterprises and nonregistered enterprises. This is achieved with the mixed design.

\section{(a) Informal businesses sample frame}

9. Table 2 shows the relevant sucos to be used in the household sample.

Table 2: Geocodes ${ }^{13}$ and names of the 42 urban sucos in Dili (31), Maliana (5) and Baucau (6) by district and posto ${ }^{14}$

\begin{tabular}{|c|c|c|c|c|c|}
\hline \multicolumn{2}{|c|}{ Dili District } & \multicolumn{2}{|c|}{ Dili District } & \multicolumn{2}{|c|}{ Baucau District } \\
\hline \multicolumn{2}{|c|}{ Posto Cristo Rei } & \multicolumn{2}{|c|}{ Posto Nein Feto } & \multicolumn{2}{|c|}{ Posto Baucau } \\
\hline 60201 & Culuhum & 60501 & Monumento & 30201 & Tiri Lolo \\
\hline 60202 & $\begin{array}{r}\text { Centro } \\
\text { Benemauk }\end{array}$ & 60502 & Asucai Lorosae & 30202 & Bahu \\
\hline 60204 & Becora & 60503 & Solo & 30203 & Caibada Uaimua \\
\hline 60208 & Camea & 60504 & Santa Cruz & 30206 & Caibada Macasae \\
\hline 60209 & Meti Aut & 60505 & Meira & 30302 & Gariway \\
\hline \multirow[t]{3}{*}{60210} & Bidau Santana & 60507 & Talera Hun & 30304 & Wailili \\
\hline & & 60508 & Bemori & & \\
\hline & & 60509 & $\begin{array}{c}\text { Lahane } \\
\text { Oriental }\end{array}$ & \multicolumn{2}{|c|}{ Bobonaro District } \\
\hline \multicolumn{2}{|c|}{ Posto Dom Aleixo } & \multicolumn{2}{|c|}{ Posto Vera Cruz } & \multicolumn{2}{|c|}{ Posto Maliana } \\
\hline 60302 & Beira Mar & 60601 & Alto Hospital & 040601 & Lahomea \\
\hline 60303 & Nazare & 60602 & Hanso Hatora & 040602 & Raifun \\
\hline 60304 & Suleur & 60603 & Bairo Alto & 040603 & Ritabou \\
\hline 60305 & 28 Novembro & 60604 & Mascarinhas & 040604 & Odomau \\
\hline 60306 & Malinamoc & 60605 & Rumbia & 040605 & Holsa \\
\hline 60307 & 12 Novembro & 60606 & Naroman & & \\
\hline 60308 & 7 Decembro & 60607 & Haksolok & & \\
\hline 60309 & 20 Maio & 60608 & Isolado & & \\
\hline 60310 & Rai Naca Doco & & & & \\
\hline
\end{tabular}

Table 3 gives the number of households in the two analytical domains Dili and non-Dili (Dili and Baucau/Maliana) according to the Suco survey.

\footnotetext{
13 Timor Leste is divided into 13 major units called distritos (districts). These are further subdivided into 67 postos (sub-districts), 498 sucos (villages) and 2,336 aldeias (sub-villages). The administrative structure is uniform throughout the country, including rural and urban areas. Each unit is uniquely identified by means of a numeric, hierarchical geocode with 2 digits for the district, 2 digits for the posto within the district, 2 digits for the suco within the posto and 2 digits for the aldeia within the suco.

${ }^{14}$ The sucos chosen as urban in the sample frame are done so with reference to the sampling of the "Timor Leste Living Standards Measurement Survey (TLSS)”, especially (Munoz 2001).
} 
Table 3: Number of households in urban Dili, Baucau and Maliana

\begin{tabular}{|c|c|}
\hline Strata & Number of households \\
\hline Urban Dili & 20,530 \\
\hline Urban Baucau & 3,651 \\
\hline Urban Maliana & 3,531 \\
\hline Total & 27,712 \\
\hline
\end{tabular}

\section{Sampling Allocation}

10. Table 3 shows that the sample needs to be stratified. If we make the following assumptions: We need a dataset of 475 informal businesses, one third of all households have an informal business; then we need a sample of $3 * 475$, which is equal to approximately 1,425 households. A non-stratified sample of 475 informal businesses (1425 households) would have a uniform sample fraction of approximately $1 / 19$, which means it would entail contacting 1,070 Dili households, resulting in approximately 360 informal business and 185 households in both Maliana and Baucau, resulting in approximately 60 informal businesses in each city. This is too few to sustain significant analysis.

11. The sample was allocated such that 295 informal businesses are targeted in the Dili and 180 were targeted in Maliana and Baucau, which gives a more even distribution. This means that according to the estimation, that $3 * 295=885$ households will be targeted in Dili and $3 * 90=270$ households in each of Maliana and Baucau.

\section{Sampling strategy}

12. The survey team had a composition of one Team Leader (DIT), three researchers/coordinators, and 22 assistant researchers. The survey team formed three field teams where the researchers coordinate the work in each urban centre.

13. The survey teams visited each stratum according to the following 2-stage procedure. In the first stage, aldeias were selected with equal probability. In each aldeia 5 informal businesses (approximately 15 households) are selected and visited. This means that 18 aldeias were visited in both Baucau and Maliana and 59 aldeias were visited in Dili. In all sampling stages sucos and aldeias are chosen with equal probability (EP). ${ }^{15}$ The strategy provides a sample that is relatively well spread.

Table 4 summarizes the situation:

\footnotetext{
${ }^{15}$ The statistics department was unable to provide the number of households for each aldeia, which would have enabled sampling of the aldeias according to probability according to size (PPS). Instead EP is used, which is still a defendable solution not harming the sampling significantly. In practice this means that it is assumed that all aldeias have the same size in terms of households.
} 
Table 4: Sample of informal businesses per stratum

\begin{tabular}{|l|c|c|c|c|c|}
\hline Stratum & Aldeias & $\begin{array}{c}\text { Informal } \\
\text { businesses }\end{array}$ & Households & $\begin{array}{c}\text { Total } \\
\text { number of } \\
\text { households }\end{array}$ & $\begin{array}{c}\text { Nominal } \\
\text { sampling } \\
\text { fraction of } \\
\text { households }\end{array}$ \\
\hline $\begin{array}{l}\text { Urban } \\
\text { Dili }\end{array}$ & 59 & 295 & 885 & 20,530 & $1 / 23.2$ \\
\hline $\begin{array}{l}\text { Urban } \\
\text { Baucau }\end{array}$ & 18 & 90 & 270 & 3,651 & $1 / 13.5$ \\
\hline $\begin{array}{l}\text { Urban } \\
\text { Maliana }\end{array}$ & 18 & 90 & 270 & 3,531 & $1 / 13.1$ \\
\hline Total & 94 & 475 & 1,425 & 27,712 & \\
\hline
\end{tabular}

\section{Implementation of sampling stages}

15. With sampling design depicted above in Table 4, the implementation of the sampling stages is as follows:

- The sample frame stemming from the suco-survey consists of three spreadsheets in which district, sub district, socu and aldeia names are listed with their geocodes for each of Baucau, Maliana and Dili.

- The sample of aldeias was done selected independently in each stratum as follows:

- In Urban Dili, all 208 aldeias were listed with their respective unique geocodes. From these 59 aldeias were selected randomly. In Dili of the sample, 10 aldeias extra were chosen to be used in the pilot survey.

- In Urban Baucau, all 32 aldeias were listed with their respective unique geocodes. From these 18 aldeias were selected.

- In Urban Maliana, all 29 aldeias were listed with their respective unique geocodes. From these 18 aldeias were selected.

\section{Sampling inside the aldeias}

16. The interviewers conducted systematic random sampling in each aldeia. In the TLSS this sampling was done via a household listing operation, in which all households were listed and the required number of households selected randomly. This process is rather strenuous and was beyond the data collection possibilities of the present survey.

17. Therefore in the present survey a simpler and probably as efficient technique was chosen including the following steps:

- The interviewers contacted the aldeia chief or another knowledgeable person in the aldeia to get the approximate number of household in the Aldeia.

- $\quad$ The number collected was divided by 15 .

- The interviewer went around the aldeia anti-clockwise visiting every number of households/15 turning left at every street corner.

- If there were more than two households in an address, the address was counted appropriately. 
- If the interviewers got right around the aldeia without having located enough households (informal businesses) to make up the cluster, then they did the route one more time selecting the households that were neighbours to the already selected households. In case of larger aldeias, the interviewers crossed the street of the first household selected and continued the route around the aldeia.

\section{Selection probabilities}

18. In urban Dili, urban Baucau and urban Maliana the probability of selecting an aldeia $i j$ in stratum $i$ was:

$P_{i j}=m_{i} / n_{i}$

Where $n_{i}$ is the total number of aldeias in the stratum and $m_{i}$ is the number of aldeias selected in the stratum. Both $m_{i}$ and $n_{i}$ are given in section 3.3, for example 50 and 208 in urban Dili.

19. The probability of selecting household $\mathrm{P}_{\mathrm{ijk}}$ with the assumption that all aldeias are of equal size in terms of households is:

$\mathrm{P}_{\mathrm{ijk}}=P_{i j} 15 /\left(\mathrm{n}_{\mathrm{ij}} / n_{i}\right)=\left(m_{i} / n_{i}\right) * 15 * n_{i} / \mathrm{n}_{\mathrm{ij}}=15 * m_{i} / \mathrm{n}_{\mathrm{ij}}$

Where $n_{i j}$ is the number of households in the stratum.

The selection probability $\mathrm{P}_{\mathrm{ijk}}$ is then $1 / 23.2,1 / 13.5$ and 1/13.1 in Dili, Baucau and Maliana respectively. This is the number of households selected in the stratum divided by the total number of households in the stratum.

\section{(b) Formal business sample frame}

20. The business register in Timor-Leste represented the sample frame for the formal of the sampling. The business register has the following characteristics of the enterprises:

- District

- Nationality of ownership

- Individual businesses or company with more employees

- Date of registration

- Business register number

- Company name

- Address

- Phone-number

21. Table 5 shows the distribution of businesses by district, nationality (Timorese, foreign) and type (company, single person) respectively for business registered in 2002 and 2003. 
Table 5: Distribution of enterprises

\begin{tabular}{|l|c|c|c|c|c|c|c|}
\hline & \multicolumn{3}{|c|}{ Timorese } & \multicolumn{5}{c|}{ Foreign } & Total \\
\hline & $\begin{array}{c}\text { Large } \\
\text { enterprise* }\end{array}$ & $\begin{array}{c}\text { Enterprise } \\
\text { (more than } \\
\text { one person) }\end{array}$ & $\begin{array}{c}\text { Single } \\
\text { person } \\
\text { enterprise }\end{array}$ & $\begin{array}{c}\text { Large } \\
\text { enterpri } \\
\text { se* }\end{array}$ & $\begin{array}{c}\text { Enterpri } \\
\text { se } \\
\text { (more } \\
\text { than one } \\
\text { person) }\end{array}$ & $\begin{array}{c}\text { Single } \\
\text { person } \\
\text { enterpri } \\
\text { se }\end{array}$ & \\
\hline Dili & 0 & 867 & 662 & 15 & 342 & 59 & 1945 \\
\hline Baucau & 0 & 33 & 20 & 0 & 0 & 0 & 53 \\
\hline $\begin{array}{l}\text { Malian } \\
\text { a }\end{array}$ & 0 & 24 & 15 & 0 & 1 & 0 & 40 \\
\hline Total & 0 & 924 & 697 & 15 & 343 & 59 & 2038 \\
\hline
\end{tabular}

*Large enterprises were chosen from the business register via local WB employees pinpointing enterprises known to be very large (approximately more than 100 employees and turnover above USD 1,000,000).

\section{Sampling Allocation and sampling strategy}

22. To reach 475 responses from the formal sector part of the survey, it was necessary to sample 1,188 businesses assuming a response rate of 40 percent (based on experience with earlier surveys).

23. With the distribution of enterprises depicted in Table 5 above, the sample needed to be disproportionably stratified. A non-stratified sample allocation would mean that almost no businesses would be chosen in the non-Dili area. The sample was stratified to further the chances that a sufficient number of businesses were included in the important analytical domain of nonDili.

24. The first step given the small number of businesses in Baucau and Maliana was therefore to sample all these businesses (93 in all) (selection probability (p) =1). In the Dili area, the following criteria were applied:

- $\quad$ All large businesses (15) were be chosen since they were a small number and were easy to identify from the business register $(\mathrm{p}=1)$.

- $\quad$ The remaining 1,080 sampling units were sampled so that the enterprises with employees were selected in 80 percent of the remaining sampling units and 20 percent of the remaining sampling units were individual enterprises.

- The proportional distribution of foreign and Timorese enterprises was upheld in the remaining part of the sample. 
Table 6: Sample of formal businesses per stratum

\begin{tabular}{|l|c|c|c|c|}
\hline \multicolumn{1}{|c|}{ Stratum } & $\begin{array}{c}\text { Formal } \\
\text { enterprises }\end{array}$ & $\begin{array}{c}\text { Expected } \\
\text { responses }\end{array}$ & $\begin{array}{c}\text { Total } \\
\text { number of } \\
\text { enterprises }\end{array}$ & $\begin{array}{c}\text { Nominal } \\
\text { sampling } \\
\text { fraction }\end{array}$ \\
\hline Dili/Timorese/Enterprise & 620 & 204.8 & 867 & $1 / 1.4$ \\
\hline Dili/Timorese/single & 198 & 65.6 & 662 & $1 / 1.34$ \\
\hline Dili/large enterprise & 15 & 6 & 15 & 1 \\
\hline Dili/foreign/enterprise & 244 & 80.8 & 342 & $1 / 1.4$ \\
\hline Dili/foreign/single & 18 & 6 & 59 & $1 / 1.33$ \\
\hline Baucau/Timorese/enterprise & 33 & 13.2 & 33 & 1 \\
\hline Baucau/Timorese/single & 20 & 8 & 20 & 1 \\
\hline Maliana/Timorese/enterprise & 24 & 9.6 & 24 & 1 \\
\hline Maliana/Timorese/single & 15 & 6 & 15 & 1 \\
\hline Maliana/foreign/enterprise & 1 & 0.4 & 1 & 1 \\
\hline Total & 1188 & 475 & 2038 & \\
\hline
\end{tabular}

\section{Implementation of sampling stages}

25. The enterprises were sampled independently in each stratum (specified in Table 6 above), with equal probability of being picked.

\section{Non-response analysis}

26. It was important for the representativeness of the sample that the enterprises that did not wish to answer or did not exist not did differ significantly from the enterprises that did answer. When data were collected, a non-response analysis was conducted comparing the characteristics (single/enterprise; foreign/Timorese, district) of the enterprises that responded with the enterprises that did not. 


\section{Annex 2: $\quad$ Definition of Worker Categories in the UES Questionnaires}

Manual workers: workers who possess the skills and proficiency, with or without academic qualifications, to carry out work related directly or indirectly to the production of material goods or services by the use of techniques, instruments or machines and to maintain and repair them. In general terms, the skills can be acquired either by prior training or by experience at work (e.g. textile operative, packer, production assistant, construction worker, etc.).

Service workers: workers whose functions include the supply of a service directed towards the satisfaction of certain personal or social needs, such as janitors, messengers, caretakers, gardeners, street vendors, sales persons etc.

Administrative workers: those who assist or support the administration in its work of management (e.g. archivist, office workers, filing clerk, secretary etc.).

Technical and professional workers: persons who apply their knowledge of scientific and technical methods to the area of production (agricultural or industrial) or to the economic, social, legal, educational or health sectors, or who carry out activities that involve explaining, executing and investigating the general laws required by the various processes of an economic and social activity.

Managerial workers: persons who specialize in planning, organizing, coordinating or directing, on their own responsibility and within the authority conferred on them, the activities of an organization, enterprise or institution, whether state, private or mixed. 


\section{Annex 3: $\quad$ Definition of skills in the UES questionnaires}

- Numeracy skills: Being able to calculate and deal with money

- Literacy skills: Being able to construct sentences correctly, write an e-mail or a letter

- English skills: Being able to speak English well

- Portuguese skills: Being able to speak Portuguese well

- Technical and practical skills: Technical skills that are required to work within a specific occupation

- Customer handling skills: Courtesy and approachability of the staff.

- Management skills: Ability to manage other employees or being able to manage your own work

- Administrative skills: Ability to handle administrative procedures and do administrative work.

- Financial skills: Ability to do financial work for the companies.

- Driving skills: Ability to drive a car, van or truck dependent on the job.

- Basic computer skills: Ability to use standard computer programs and familiarity with a keyboard.

- Advanced IT-skills: Ability to handle more complex software, maintain systems, and taking the knowledge of computers to the next level

- Marketing skills: Ability to promote the company via promotion material, network or other promotions

- Negotiating skills: Ability to bargain and negotiate for the company. 


\section{Annex 4: Key Macroeconomic Indicators}

\begin{tabular}{|c|c|c|c|c|c|c|}
\hline & 1999 & 2000 & $\begin{array}{l}2001 \\
\text { Estimates }\end{array}$ & 2002 & 2003 & $\begin{array}{l}2004 \\
\text { Projected }\end{array}$ \\
\hline $\begin{array}{l}\text { GNP at current prices (in } \\
\text { millions of U.S. dollars) }\end{array}$ & 270 & 329 & 400 & 397 & 372 & 370 \\
\hline GDP & 270 & 321 & 387 & 381 & 341 & 328 \\
\hline $\begin{array}{l}\text { Real GDP growth } \\
\text { (percentage change) }\end{array}$ & -35 & 15 & 15 & -6.7 & -6.2 & 3.4 \\
\hline $\begin{array}{l}\text { Inflation (percentage change } \\
\text { at end-period) } 1 / 2 /\end{array}$ & 140 & 3 & 0 & 9.5 & 4.2 & 1.8 \\
\hline \multicolumn{7}{|c|}{$\begin{array}{l}\text { 1/ Rupiah-based CPI for Dili through } 2000 \text { and, thereafter, dollar-based CPI for Dili. } \\
\text { 2/ The figure for } 2004 \text { relates to April. }\end{array}$} \\
\hline
\end{tabular}

